\title{
DAMPAK DESENTRALISASI FISKAL TERHADAP KONVERGENSI PENDAPATAN PERKAPITA ANTAR KABUPATEN/KOTA DI INDONESIA
}

\author{
Bonnie Permana Negara \\ Direktorat Jenderal Perbendaharaan \\ Khoirunurrofik \\ Universitas Indonesia \\ Alamat Korespondensi: bonipermana@gmail.com
}

\begin{abstract}
Using panel data of 505 regencies/municipalities in Indonesia during the implementation period of decentralisation from 2001-2017, this study aims to examine indications of economic convergence between regions in Indonesia and to determine the effect of fiscal decentralisation policies on the convergence of per capita income between regions in Indonesia. The fiscal decentralisation indicator in this study uses income indicators and regional expenditure indicators. Regional income indicators consist of local revenue, revenue sharing funds and transfer funds. Regional expenditure indicators focus on spending on the education sector, the health sector, and the infrastructure sector. Using a static convergence analysis, this study found evidence that there was a convergence of per capita income between regencies/municipalities in Indonesia. Analysis of dynamic convergence with absolute convergence and conditional convergence models. The absolute convergence model estimation results show the convergence of per capita income between regencies/municipalities in Indonesia with a convergence rate of 7 percent. While the estimation results of the conditional convergence model produce a convergence rate of 18 percent when labor, investment, education participation rates, and indicators of fiscal decentralisation are included in the model. Based on the results of estimates, the key to increasing the speed of convergence of per capita income between regions is that local governments must improve the quality of spending according to the value for money principle.
\end{abstract}

\begin{abstract}
ABSTRAK
Dengan menggunakan data panel 505 kabupaten/kota di Indonesia selama periode pelaksanaan desentralisasi sejak tahun 2001 sampai dengan 2017, penelitian ini bertujuan untuk menguji tentang indikasi konvergensi perekonomian antar daerah di Indonesia dan untuk mengetahui pengaruh kebijakan desentralisasi fiskal terhadap konvergensi pendapatan per kapita antar daerah di Indonesia. Indikator desentralisasi fiskal pada penelitian ini menggunakan indikator pendapatan daerah dan indikator belanja daerah. Indikator pendapatan daerah terdiri dari pendapatatan asli daerah, dana bagi hasil, dan dana transfer. Indikator belanja daerah fokus pada belanja sektor pendidikan, kesehatan, dan infrastruktur. Menggunakan analisis konvergensi statis, penelitian ini menemukan bukti bahwa terjadi konvergensi pendapatan per kapita antar kabupaten/kota di Indonesia. Analisis konvergensi dinamis dengan model absolute convergence dan conditional convergence. Hasil estimasi model absolute convergence menunjukkan terjadinya konvergensi pendapatan per kapita antar kabupaten/kota di Indonesia dengan tingkat konvergensi sebesar 7 persen. Sedangkan hasil estimasi model conditional convergence menghasilkan tingkat konvergensi sebesar 18 persen ketika tenaga kerja, investasi, angka partisipasi pendidikan, dan indikator desentralisasi fiskal disertakan dalam model. Berdasarkan hasil estimasi maka kunci untuk meningkatkan kecepatan konvergensi pendapatan per kapita antar daerah adalah pemerintah daerah harus meningkatkan kualitas belanja mengacu pada prinsip value for money.
\end{abstract}

KATA KUNCI:

Desentralisasi Fiskal, Pembangunan Ekonomi, Convergence

KLASIFIKASI JEL:

E620; H720; 0470

CARA MENGUTIP:

Negara, B. P. \& Khoirunurrofik. (2021). Dampak desentralisasi fiskal terhadap konvergensi pendapatan perkapita antar kabupaten/kota di Indonesia. Indonesian Treasury Review: Jurnal Perbendaharaan, Keuangan Negara dan Kebijakan Publik, 6(1), 1-18. 


\section{PENDAHULUAN}

\subsection{Latar Belakang}

Desentralisasi fiskal di Indonesia pada awal tahun 2001 merupakan sebuah fenomena big bang decentralization di mana terdapat pelimpahan wewenang dan urusan dari pusat ke daerah, yang dilakukan secara penuh untuk urusan pengeluaran daerah, serta sebagian wewenang dalam memungut pajak daerah dan retribusi daerah. Perpindahan sistem dari sentralisasi ke desentralisasi memberikan implikasi yang cukup besar terhadap pengelolaan fiskal pada level pemerintahan kabupaten/kota, meliputi peningkatan rasio belanja pemerintah daerah terhadap belanja pemerintah pusat yang mencapai 30 persen, peningkatan pengeluaran pemerintah daerah dengan rata-rata sebesar 40 persen, dan berlakunya sistem fiskal antar tingkat pemerintah yang baru dan lebih baik (Hofman and Kaiser, 2002). Konsekuensi dari pelaksanaan sistem desentralisasi adalah adanya desentralisasi fiskal antar tingkatan pemerintah untuk menjamin pelaksanaan urusan pemerintah daerah dalam penyelenggaraan pelayanan publik kepada masyarakat.

Desentralisasi fiskal berfungsi meningkatkan efisiensi pada sektor publik sehingga berdampak pada pertumbuhan dan pembangunan ekonomi jangka panjang. Keunggulan informasi dan pengetahuan yang sempurna tentang sumber daya daerah membuat pemerintah daerah mampu menyelenggarakan pelayanan publik sesuai preferensi dan kebutuhan masyarakat dengan biaya yang efisien (Tiebout, 1956; Oates, 1972). Penerapan desentralisasi fiskal merupakan bagian dari stategi pembangunan yang akan mengarah pada pertumbuhan yang lebih baik dan meningkatkan stabilisasi makroekonomi (Bird and Vaillancourt, 1998:1; Bahl, 1999).

Fenomena big bang decentralization di Indonesia diimplementasikan sepenuhnya di level pemerintahan paling bawah yaitu pemerintahan kabupaten dan kota. Antara pemerintahan kota dan kabupaten mempunyai beberapa perbedaan karakteristik, yaitu dari a) struktur ekonomi di kota sebagian besar ditopang oleh sektor industri dan jasa sedangkan di kabupaten lebih cenderung ditopang oleh sektor pertanian, perikanan, dan pertambangan; b) tingkat kepadatan penduduk di kota cenderung lebih tinggi daripada di kabupaten; c) luas wilayah di kota cenderung relatif lebih sempit daripada di kabupaten; d) akses infrastruktur sosial, fasilitas, dan kualitas pendidikan, serta kesehatan di kota lebih baik daripada di kabupaten; e) untuk struktur pemerintahan di kota lebih ramping sampai dengan level kelurahan sedangkan di kabupaten terdapat pemerintahan level desa dan dusun; f) beban kota lebih berat daripada kabupaten karena terdapat spillover atas status kota sebagai pusat pelayanan yang mendukung kabupatenkabupaten di sekitarnya; (g) Pendapatan Domestik Regional Bruto (PDRB) kota cenderung lebih tinggi daripada kabupaten yang berimplikasi tingginya penerimaan pajak daerah dan retribusi di level kota sehingga ketergantungan fiskal di level kota terhadap dana transfer dari pusat cenderung lebih rendah daripada di level kabupaten.

Perbedaan karakteristik antara pemerintahan kota dan kabupaten tersebut penting untuk melihat a) apakah perekonomian antar kabupaten/kota di Indonesia menunjukkan indikasi konvergen; b) apakah implementasi desentralisasi fiskal membantu daerah khususnya kabupaten dapat mengejar ketertinggalan perekonomian dari kota. Dengan demikian, tujuan penelitian ini adalah untuk mengetahui bagaimana perbedaan kecepatan konvergensi pendapatan per kapita di level kabupaten/kota, level kota, dan level kabupaten dalam merespon desentralisasi fiskal karena kota dari sisi pendapatan mempunyai kapasitas fiskal yang lebih baik dari kabupaten tetapi di sisi lain kota mempunyai beban yang lebih besar karena harus melayani daerah-daerah di sekitarnya.

Kontribusi penelitian ini adalah melihat dampak desentralisasi fiskal terhadap pertumbuhan perekonomian daerah khususnya kecepatan konvergensi pendapatan per kapita antar daerah di seluruh Indonesia. Selain itu, penelitian ini berbeda dengan penelitian yang sudah ada di mana a) data yang digunakan dalam penelitian ini menggunakan unit analisis level kabupaten/kota seluruh Indonesia dari tahun 2001-2017; dan b) penelitian ini melihat bagaimana dampak desentralisasi fiskal baik dari sisi pendapatan dan pengeluaran daerah dalam mempengaruhi kecepatan konvergensi pendapatan per kapita antar kabupaten/kota, level kota, dan level kabupaten di Indonesia.

\subsection{Desentralisasi Fiskal di Indonesia}

Dengan berjalannya sistem desentralisasi maka hampir seluruh urusan pemerintah pusat dilimpahkan ke pemerintah daerah kecuali urusan hukum peradilan, pertahanan dan keamanan, agama, fiskal dan moneter, serta kebijakan luar negeri. Kondisi tersebut memberikan konsekuensi terhadap perubahan sistem fiskal daerah di mana kebutuhan fiskal daerah menjadi lebih tinggi sedangkan kapasitas fiskal daerah relatif tidak mengalami perubahan signifikan, kecuali daerah yang memiliki basis sumber daya alam yang melimpah. Untuk menutup celah fiskal di daerah maka pemerintah pusat memberikan block grant kepada daerah berupa dana bagi hasil (DBH) baik 
pajak maupun non pajak, dana alokasi umum (DAU), dan dana alokasi khusus (DAK). Transfer yang diberikan pusat kepada daerah adalah untuk menjamin penyelenggaraan pemerintahan dan pelaksanaan pelayanan publik di daerah sesuai standar yang telah ditetapkan. Dalam perjalanan era desentralisasi fiskal selama tujuh belas tahun, ternyata dari gambar 1 diketahui bahwa dari tahun 2001 sampai dengan 2017 tidak ada perkembangan yang berarti terhadap perubahan besaran transfer pusat ke masing-masing daerah. Besaran transfer pusat ke daerah dari tahun 2001 sampai 2017 proporsinya masih di atas 50 persen walaupun beberapa daerah menunjukkan adanya tren penurunan. Hal tersebut memberikan arti bahwa selama pelaksanaan desentralisasi fiskal hampir seluruh daerah baik kabupaten maupun kota mengalami ketergantungan dana transfer dari pusat.

Gambar 1. Perkembangan Dana Transfer (DAU, DAK, DBH) Antar Daerah Periode 2001-2017

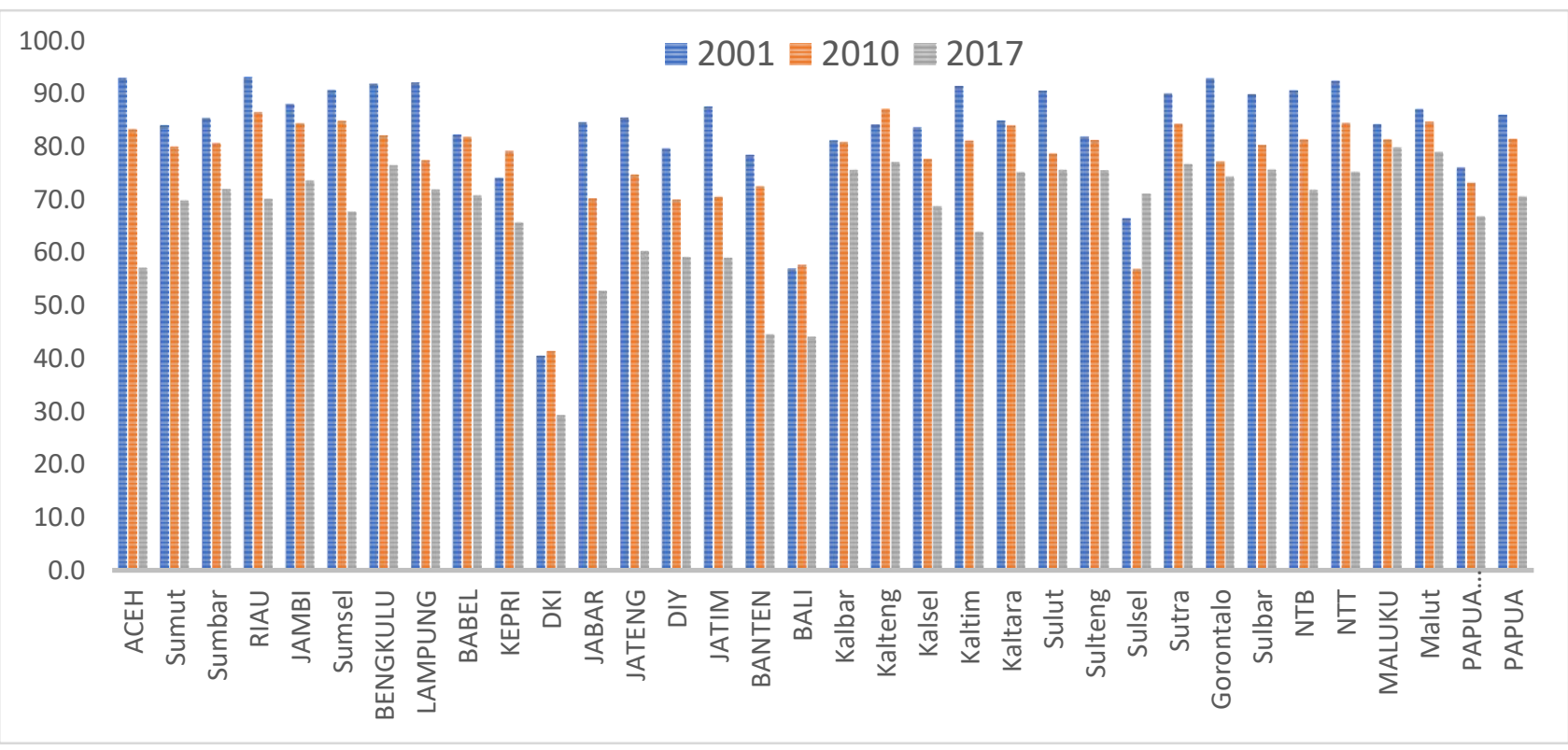

Sumber: Kementerian Keuangan dan BPS

Pemerintah daerah melalui Anggaran Pendapatan dan Belanja Daerah (APBD) dapat mengarahkan dan menjamin kesinambungan pembangunan, serta meningkatkan kualitas hidup masyarakat di daerah. Salah satu pos di dalam anggaran yang digunakan oleh pemerintah daerah untuk mencapai tujuan tersebut adalah belanja langsung, yakni belanja yang secara langsung terkait dengan program dan kegiatan yang bersentuhan langsung dengan pelayanan publik. Jika pemerintah daerah dalam mengelola APBD memberikan porsi alokasi yang dominan pada belanja langsung yang terkait dengan aktivitas pembangunan ekonomi daerah, maka hal tersebut akan memberikan dampak positif bagi pertumbuhan ekonomi daerah, tersedianya lapangan kerja, menurunnya angka kemiskinan, dan berkurangnya kesenjangan pendapatan antara si kaya dan si miskin. Capaian dalam pembangunan ekonomi daerah banyak dipengaruhi oleh peran pemerintah daerah yang manifestasinya terdapat pada pengalokasian anggaran dalam bentuk belanja langsung di bidang pembangunan sosial dan ekonomi khususnya bidang pendidikan, kesehatan, dan infrastruktur. Selama ini pembangunan ekonomi selalu menjadi prioritas utama dalam tujuan pembangunan nasional.

Memasuki dua dekade perjalanan era desentralisasi di Indonesia, maka perlu dilihat sejauh mana perkembangan desentralisasi terutama desentralisasi fiskal mempengaruhi kondisi makroekonomi di level kabupaten dan kota yang berdampak pada pembangunan ekonomi secara nasional. Pada umumnya indikator pembangunan ekonomi dapat diukur dari tingkat pertumbuhan ekonomi dan penurunan ketimpangan pendapatan. Dari gambar 2 dan 3 diketahui bagaimana pengaruh rata-rata dana transfer yang terdiri dari $\mathrm{DBH}, \mathrm{DAK}$, dan DAU terhadap rata-rata pertumbuhan ekonomi dan rasio gini pada tahun 2006-2017. Terdapat hal yang cukup menarik dimana daerah-daerah yang mendapat dana transfer yang rendah cenderung mengalami tingkat pertumbuhan ekonomi yang tinggi dan sebaliknya daerah yang mendapat dana transfer yang tinggi cenderung mengalami tingkat pertumbuhan ekonomi yang rendah (antara dana transfer dan pertumbuhan ekonomi mempunyai hubungan yang negatif). 
Gambar 2. Rerata Growth terhadap Rerata Dana

Transfer (DAU, DAK, DBH) Periode 2006-2017

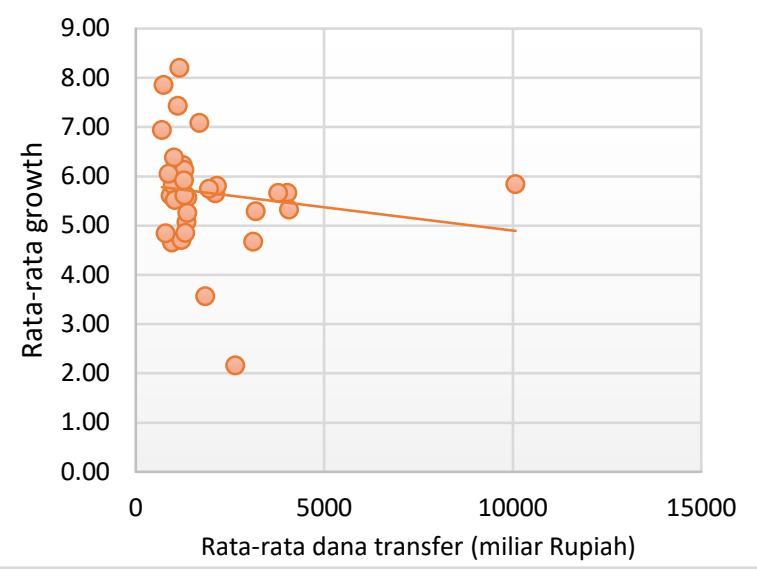

Sumber: Kementerian Keuangan dan BPS

Sedangkan untuk rasio gini mengalami kecenderungan tinggi pada daerah yang mendapat dana transfer yang tinggi dan sebaliknya rasio gini mengalami kecenderungan rendah pada daerah yang mendapat dana transfer rendah (antara dana transfer dan rasio gini mempunyai hubungan yang positif). Menilik fenomena yang disajikan pada scatter plot pada gambar 2 dan 3, masih belum bisa disimpulkan apakah desentralisasi fiskal yang berkembang di Indonesia selama hampir dua dekade ini mendekati arah pembangunan ekonomi yang ideal di mana desain kebijakan desentralisasi fiskal baik dari expenditure side maupun revenue side berdampak pada peningkatan pertumbuhan ekonomi dan pengurangan ketimpangan pendapatan secara nasional.

Gambar 3. Rerata Gini Rasio Terhadap Rerata

Dana Transfer (DAU, DAK, DBH) Periode 20062017

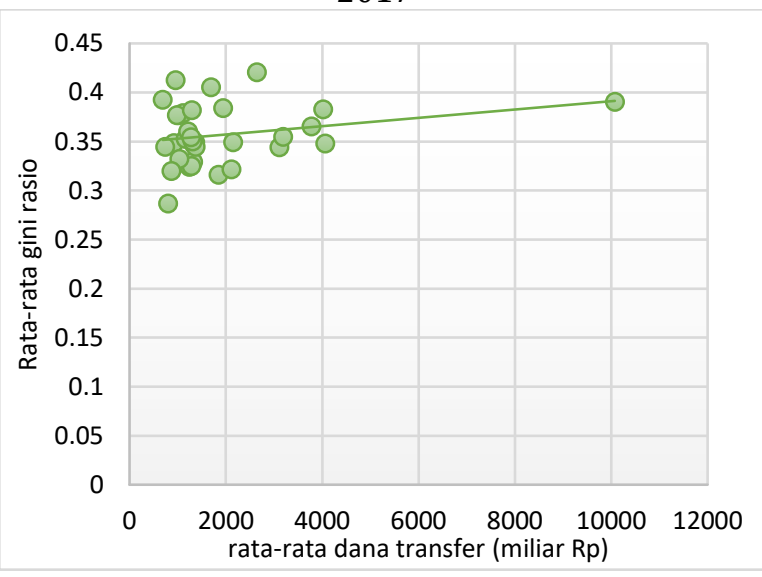

Sumber: Kementerian Keuangan dan BPS

Salah satu indikator untuk melihat pengaruh kebijakan desentralisasi fiskal terhadap indikator pembangunan ekonomi baik pertumbuhan ekonomi maupun pemerataan pendapatan masyarakat adalah apakah terjadi konvergensi perekonomian antar daerah di level yang paling rendah selama periode otonomi daerah (Bartolini,
Stossberg, and Blöchliger, 2016). Jika terjadi konvergensi antar perekonomian maka desain kebijakan desentralisasi fiskal sudah berada di jalur yang tepat. Adanya konvergensi dapat diartikan bahwa terjadi perbaikan tingkat pemerataan pendapatan masyarakat antar daerah dalam jangka panjang. Pada akhirnya peran untuk mereduksi kesenjangan pendapatan per kapita antar daerah dapat dilakukan oleh desentralisasi fiskal terutama ketepatan desain intergovernmental transfer yang dibangun oleh pemerintah pusat dapat mempercepat konvergensi antar daerah yang mempengaruhi tingkat pertumbuhan ekonomi jangka panjang (Ogawa and Yakita, 2009).

\section{LANDASAN TEORI}

\subsection{Desentralisasi Fiskal}

Model Musgrave terkait kewenangan sektor publik diklasifikasikan dalam 3 fungsi, yaitu: (a) fungsi stabilisasi yaitu peran pemerintah untuk menjamin sekaligus menjaga stabilitas perekonomian secara makro dalam rangka mencapai stabilitas nasional; (b) fungsi distribusi adalah peran pemerintah untuk mendistribusikan sumber-sumber ekonomi (pendapatan) kepada seluruh masyarakat; dan (c) fungsi alokasi adalah peran pemerintah untuk membagikan alokasi sumber daya ekonomi yang ada dalam perekonomian kepada seluruh masyarakat. Teori desentralisasi memberikan arahan untuk berbagi fungsi-fungsi ini di antara berbagai tingkat pemerintahan di mana fungsi stabilisasi dan fungsi distribusi lebih efisien jika dilakukan oleh pemerintah pusat sedangkan fungsi alokasi sumber daya ekonomi dalam penyediaan barang publik sebaiknya dilaksanakan oleh pemerintah daerah karena pemanfaatan barang publik dapat dibatasi oleh ruang (Musgrave, 1991:9). Peran yang ditentukan dari tingkat pemerintahan yang terdesentralisasi dalam fungsi alokasi sangat besar karena permintaan untuk banyak pelayanan publik di berbagai daerah tidak mungkin seragam. Dengan demikian, kesejahteraan akan ditingkatkan melalui desentralisasi karena penduduk di wilayah hukum yang berbeda dapat memilih kombinasi antara barang publik dan pajak yang paling sesuai dengan preferensi mereka.

Menurut Bahl \& Linn (1994) model Musgrave tersebut di atas menjadi titik awal untuk membahas pembagian kekuatan fiskal dan tanggung jawab di antara tingkatan pemerintahan. Stimulasi pertumbuhan ekonomi yang stabil dan distribusi pendapatan menjadi tanggung jawab dari pemerintah pusat. Sedangkan fungsi alokasi sebagai peran utama bagi pemerintah daerah, yaitu keputusan tentang berapa banyak yang 
harus dibelanjakan untuk setiap layanan dan bagaimana cara membiayai pengeluaran ini. Hal tersebut dikarenakan pemerintah daerah paling dekat dengan masyarakat lokal dan berada dalam posisi terbaik untuk mengetahui preferensi lokal untuk pelayanan publik dan untuk berbagai jenis pajak serta retribusi. Tingkat desentralisasi yang tepat tergantung pada bagaimana efisiensi diperoleh dari kedekatan pemerintah dengan masyarakat dibandingkan dengan keuntungan yang dihasilkan dari memberikan keleluasaan lebih kepada pemerintah pusat untuk mengelola kebijakan fiskal.

Menurut Tanzi (1995) eksistensi desentralisasi fiskal dapat dilihat ketika pemerintah daerah memiliki kekuasaan untuk memungut dan mengelola pajak serta melakukan kegiatan pengeluaran dalam kriteria hukum yang ditetapkan dengan jelas. Desentralisasi fiskal merupakan bagian dari strategi desentralisasi agar efisien di mana a) pemerintah lokal harus didelegasikan tanggung jawab spesifik dan penting serta pemerintah lokal harus mempunyai kebebasan dalam menentukan pengeluaran dan memiliki kapasitas administratif untuk melaksanakan tanggung jawab; dan b) pemerintah lokal harus memiliki kemampuan untuk menarik pajak daerah dan menerima transfer tanpa syarat. Tingkatan desentralisasi fiskal dari suatu pemerintahan ditentukan oleh sejauh mana otonomi pengambilan keputusan fiskal dilimpahkan ke dan dilaksanakan oleh pemerintah daerah yang dipilih secara independen oleh masyarakat lokal. Semakin banyak fungsi yang dilimpahkan ke daerah dan semakin banyak jenis pajak yang dikelola daerah maka semakin tinggi tingkatan desentralisasi fiskal yang dilaksanakan suatu pemerintahan. Desain desentralisasi fiskal dalam suatu pemerintahan melibatkan beberapa dimensi seperti berikut ini: (i) desentralisasi pada expenditure-side and revenue-side, dengan beragam tugas yang didelegasikan; (ii) hanya desentralisasi pengeluaran (expenditure-side) yang dapat dilakukan; (iii) desentralisasi dengan big-bang approach, melimpahkan semua tugas untuk didesentralisasi ke pemerintah daerah dalam satu waktu; (iv) dilakukan secara bertahap, dengan tugas yang didelegasikan secara bertahap. Desain desentralisasi fiskal yang tepat jika dibarengi dengan waktu implementasi yang tepat sangat menentukan keberhasilan pelaksanaan desentralisasi fiskal suatu pemerintahan (Sato, 2004).

\subsection{Konvergensi}

Barro \& Sala-i-Martin (2004:50) menjelaskan konsep konvergensi adalah suatu kondisi perekonomian dengan tingkat pendapatan per kapita yang lebih rendah (dinyatakan relatif terhadap tingkat pendapatan per kapita steady state-nya) cenderung tumbuh lebih cepat. Konsep konvergensi berangkat dari hipotesis catching up dari Abramovitz (1986) yang menyatakan perekonomian dengan tingkat produktivitas rendah mempunyai potensi yang besar untuk mencapai tingkat pertumbuhan yang tinggi tetapi potensi tersebut menjadi lemah ketika tingkat produktivitasnya mendekati tingkat produktivitas perekonomian acuannya. Kondisi tersebutlah yang memberikan indikasi adanya proses pengejaran ketertinggalan. Terdapat dua konsep tentang terjadinya konvergensi dalam pembahasan pertumbuhan ekonomi, konsep pertama yaitu konvergensi muncul jika perekonomian dengan output rendah cenderung untuk tumbuh lebih cepat daripada perekonomian dengan output tinggi sehingga perekonomian negara miskin cenderung mengejar ketinggalan dengan negara makmur dalam hal tingkat pendapatan atau produk per kapita. Konsep kedua terkait dispersi antar wilayah yaitu konvergensi muncul jika dispersi, yang diukur dengan deviasi standar logaritma pendapatan per kapita atau produk antar negara, semakin menurun seiring waktu (Barro and Sala-i-Martin, 1990).

Konsep konvergensi yang pertama disebut $\beta$ konvergen, dengan $\beta$ konvergen dapat diketahui kecepatan konvergensi suatu perekonomian secara pasti. Untuk mengetahui seberapa cepat output per pekerja dalam suatu perekonomian mendekati nilai steady state-nya dilihat dari besaran nilai koefisien $\beta$ konvergen. Dalam studi empiris pengukuran $\beta$ konvergen dapat dilakukan dengan mengukur absolute convergence dan conditional convergence (Barro and Sala-i-Martin, 1992; Mankiw, Romer, and Weil, 1992; Islam, 1995). Absolute convergence adalah hipotesis yang menyatakan bahwa pertumbuhan ekonomi hanya dipengaruhi oleh tingkat pendapatan per kapita awal saja tanpa syarat karakteristik/faktor-faktor perekonomian lainnya. Sedangkan conditional convergence adalah hipotesis yang menyatakan pertumbuhan ekonomi suatu negara selain dipengaruhi oleh tingkat pendapatan per kapita awal tetapi juga dengan syarat karakteristik perekonomian lainnya. Konsep konvergensi yang kedua disebut sebagai $\sigma$ konvergen, untuk mengukur $\sigma$ konvergen dalam literatur ekonomi regional dapat ditemui berbagai indeks kesenjangan seperti maximum to minimum ratio, atkinson index, theil's entropy index, coefficient of variation, gini coefficient, dan relative mean deviation (Shankar and Shah, 2003).

Dalam konteks Indonesia terdapat beberapa penelitian telah membahas konvergensi pendapatan per kapita antar daerah baik sebelum maupun sesudah diberlakukan otonomi daerah. Hasil dari penelitian sebelumnya tersebut secara 
empiris memberikan temuan yang berbeda. Penelitian dari Garcia \& Soelistianingsih (1998) yang menggunakan metode cross section OLS kemudian Wibisono (2003), Resosudarmo \& Vidyattama (2006), Aritenang (2010) menggunakan metode panel OLS membuktikan bahwa perekonomian antar daerah di Indonesia, dalam hal ini di level provinsi, mengalami konvergensi. Sedangkan penelitian dari Vidyattama (2013) menggunakan metode spatial model membuktikan bahwa perekonomian antar daerah di Indonesia, dalam hal ini di level kabupaten/kota, tidak terjadi konvergensi.

Dalam penelitian sebelumnya yang membahas dampak desentralisasi fiskal terhadap konvergensi pendapatan per kapita antar daerah di Indonesia sangat jarang menggunakan unit analisis sampai dengan level kabupaten/kota. Sementara itu, basis desentralisasi yang dilaksanakan di Indonesia pada tahun 2001 adalah di level kabupaten/kota. Menurut Barro \& Sala-i-Martin (1990) konvergensi lebih dapat dicapai apabila menggunakan unit analisis dengan level paling rendah karena adanya interaksi yang lebih besar antar daerah dengan level paling rendah sebagai entitas ekonomi. Dengan demikian, penelitian ini akan fokus untuk melihat apakah pendapatan per kapita di level kabupaten/kota di seluruh Indonesia selama periode pelaksanaan desentralisasi dalam periode tahun 2001 sampai dengan 2017 mengalami konvergensi atau divergensi dengan menggunakan analisis konvergensi statis dan analisis konvergensi dinamis.

\section{METODOLOGI PENELITIAN}

\subsection{Data}

Penelitian ini menggunakan data sekunder dan bersifat data panel yaitu menggabungkan data time series (menggunakan periode waktu 17 tahun yaitu dari tahun 2001 sampai dengan 2017) dan cross section (menggunakan unit seluruh kabupaten/kota di Indonesia). Data untuk desentralisasi fiskal diperoleh dari data histori realisasi APBD Direktorat Jenderal Perimbangan Keuangan, Kementerian Keuangan Republik Indonesia dan Laporan Keuangan Pemerintah Pusat, sedangkan data yang terkait dengan ketimpangan, pertumbuhan ekonomi daerah, jumlah penduduk, pendapatan domestik regional bruto (PDRB), tenaga kerja, angka partisipasi sekolah diperoleh dari survei sosial ekonomi nasional (Susenas), publikasi Badan Pusat Statistik dan Bank Indonesia sedangkan data investasi daerah diperoleh dari publikasi Badan Koordinasi Penanaman Modal.

\subsection{Estimasi Model Konvergensi}

Untuk mengetahui indikasi konvergensi pada perekonomian regional di Indonesia maka penelitian ini akan menggunakan dua ukuran konvergensi yaitu $\sigma$ konvergen (analisis statis) dan $\beta$ konvergen (analisis dinamis). Analisa statis memberikan gambaran tentang ketidaksetaraan pada suatu titik waktu sedangkan analisis dinamis menangkap tren historis. Pada analisis $\sigma$ konvergen akan menggunakan Indeks Williamson. Indeks Williamson (IW) merupakan indeks untuk mengukur dispersi PDRB per kapita, indeks ini telah distandardisasi sehingga dapat digunakan untuk membuat perbandingan antar daerah dari waktu ke waktu. Indeks Williamson dihitung menggunakan formula berikut (Shankar and Shah, 2003):

$$
I W=\frac{\sqrt{\sum\left(y_{j}-\bar{y}\right)^{2} \frac{p_{j}}{P}}}{\bar{y}}
$$

Di mana:

$y_{j}$ adalah jumlah PDRB per kapita wilayah ke-j

$\bar{y}$ adalah jumlah PDRB per kapita rata-rata seluruh wilayah

$p_{j}$ adalah jumlah penduduk wilayah ke-j

$P$ adalah jumlah penduduk seluruh wilayah

Sedangkan untuk $\beta$ konvergen terdiri dari absolute convergence dan conditional convergence. Persamaan yang digunakan untuk absolute convergence menggunakan model dari Barro \& Sala-i-martin (1992) dengan persamaan yang menghubungkan tingkat pertumbuhan pendapatan per kapita antara dua titik waktu terhadap level awal pendapatan per kapita:

$$
\ln \left(\frac{y_{i, t}}{y_{i, t-1}}\right)=\alpha+\beta_{0} \ln \left(y_{i, t-1}\right)+u_{i, t}
$$

Sedangkan persamaan yang digunakan untuk conditional convergence sebagai berikut:

$$
\begin{aligned}
\ln \left(\frac{y_{i, t}}{y_{i, t-1}}\right)= & \alpha+\beta_{0} \ln \left(y_{i, t-1}\right) \\
& +\beta_{1} \ln (X)_{i, t}+\beta_{2} \ln (Z)_{i, t} \\
& +u_{i, t}
\end{aligned}
$$

Nilai koefisien $\beta_{0}<0$ menunjukkan bahwa perekonomian antar daerah dalam jangka panjang menunjukkan terjadinya konvergensi (semakin mengecilnya selisih pertumbuhan antar waktu sehingga perekonomian akan bergerak menuju tingkat steady state). Sedangkan jika nilai 
koefisien $\beta_{0}{ }^{1}>0$ menunjukkan bahwa perekonomian antar daerah dalam jangka panjang cenderung divergen (adanya selisih pertumbuhan antar waktu yang semakin membesar sehingga perekonomian bergerak menjauh dari tingkat steady state). Variabel independen $\left(\frac{y_{i, t}}{y_{i, t-1}}\right)$ merupakan proporsi pendapatan per kapita pada akhir periode $\left(y_{i, t}\right)$ terhadap pendapatan per kapita pada awal periode $\left(y_{i, t-1}\right)$. Pendapatan per kapita $\left(y_{i, t}\right)$ merupakan Produk Domestik Regional Bruto (PDRB) per kapita kabupaten/kota $i$ atas dasar harga konstan tahun 2010 pada tahun $t$. Variabel $(Z)_{i, t}$ adalah variabel kontrol yang menggambarkan karakteristik daerah yang terdiri dari investasi daerah baik investasi Penanaman Modal Asing (PMA) maupun investasi Penanaman Modal Dalam Negeri (PMDN), angka partisipasi sekolah kelompok umur 16 s.d. 18 tahun, dan tenaga kerja. Variabel $(X)_{i, t}$ merupakan indikator desentralisasi fiskal yang terdiri dari:

- Rasio pendapatan asli daerah (PAD) level kabupaten/kota terhadap total pendapatan pemerintah pusat, pemerintah provinsi, pemerintah kabupaten/kota (konsolidasi). Rasio ini digunakan pada penelitian Akai \& Sakata (2002); Ebel \& Yilmaz (2002).

- Rasio pendapatan transfer dana alokasi (DAU dan DAK) level kabupaten/kota terhadap total pendapatan pemerintah pusat, pemerintah provinsi, pemerintah kabupaten/kota (konsolidasi). Rasio ini digunakan pada penelitian Ebel dan Yilmaz (2002); Meloche, Vaillancourt dan Yilmaz (2004).

- Rasio pendapatan bagi hasil level kabupaten/kota terhadap total pendapatan pemerintah pusat, pemerintah provinsi, pemerintah kabupaten/kota (konsolidasi). Rasio ini digunakan pada penelitian Ebel dan Yilmaz (2002).

- Rasio pengeluaran level kabupaten/kota terhadap pengeluaran pemerintah konsolidasi (pengeluaran pusat tanpa belanja transfer, pengeluaran pemerintah provinsi, pengeluaran pemerintah kabupaten/kota). Rasio ini digunakan pada penelitian Woller \& Phillips (1998); Davoodi \& Zou (1998); Akai \& Sakata (2002); Iimi (2005).

\footnotetext{
1 Digunakan untuk menghitung kecepatan konvergensi menggunakan rumus $\lambda=-\ln \left(1+\beta_{0}\right)$ serta digunakan untuk menghitung waktu yang diperlukan menutup setengah dari kesenjangan awal (half-life of convergence) menggunakan rumus $\tau_{\text {half-life }}=\frac{\ln (2)}{\lambda}$
}

Penerapan desentralisasi fiskal di Indonesia saat ini yang telah berjalan sepenuhnya adalah desentralisasi di bidang pengeluaran, maka penulis akan memodifikasi indikator belanja berdasarkan 3 sektor yaitu belanja sektor pendidikan, kesehatan, dan infrastruktur. Pemilihan belanja daerah menurut sektor pendidikan, kesehatan, dan infrastruktur dikarenakan belanja tersebut adalah jenis belanja produktif yang mempunyai arah yang jelas dalam mempengaruhi pertumbuhan ekonomi dan ketimpangan pendapatan. Selain itu, belanja daerah pada sektor pendidikan, kesehatan, dan infrastruktur adalah gambaran dari investasi yang dimiliki oleh daerah dalam pembangunan ekonomi (Devarajan, Swaroop, and Zou, 1996). Belanja sektor infrastruktur pada penelitian ini menggunakan belanja daerah menurut klasifikasi berdasarkan fungsi yaitu klasifikasi yang didasarkan pada fungsi-fungsi utama pemerintah daerah dalam memberikan pelayanan kepada masyarakat. Belanja sektor infrastruktur dalam penelitian ini menggunakan pendekatan realisasi belanja daerah menurut fungsi fasilitas umum dan perumahan. Untuk mendapatkan hasil estimasi yang realistis maka variabel belanja menurut sektor tersebut menggunakan lag 1 tahun.

Penelitian ini menggunakan teknik estimasi robust fixed effect. Penggunaan teknik estimasi data panel tersebut disebabkan unit analisis pada penelitian ini adalah level kabupaten/kota. Dengan demikian perbedaan karakter antar kabupaten/kota diperkirakan memberikan efek yang berbeda terhadap konvergensi yang dihasilkan. Estimasi robust fixed effect menggunakan teknik variabel dummy untuk menangkap perbedaan intersep antar data dan memungkinkan adanya perubahan pada setiap $i$ dan $t$.

\section{HASIL DAN PEMBAHASAN}

\subsection{Analisa Konvergensi Statis}

Berdasarkan hasil perhitungan dari indeks IW sebagaimana terlihat pada gambar 4, selama periode pelaksanaan otonomi daerah dari tahun 2001 sampai dengan tahun 2017 diketahui bahwa perekonomian antar daerah mengalami kecenderungan konvergen. Untuk indeks IW di tahun 2001 adalah sebesar 1,329 dan mempunyai tren terus menurun tiap tahunnya tetapi pada tahun 2005 mengalami kenaikan di angka 1,276 serta tahun 2009 mengalami kenaikan di angka 1,175. Setelah tahun 2009 indeks IW terus mengalami penurunan pada tahun 2017 berada di angka 1,094. Dari hasil indeks IW tersebut memberikan bukti yang cukup kuat terhadap hipotesis $\sigma$ konvergen di mana perekonomian antar kabupaten/kota di Indonesia mengalami konvergensi selama periode otonomi daerah. 
Hasil penelitian tersebut memperkuat hasil penelitian dari Garcia \& Soelistianingsih (1998), Wibisono (2003), dan Vidyattama (2013) yang menemukan adanya konvergensi pendapatan per kapita antar kabupaten/kota antara tahun 1999 sampai dengan 2008 walaupun ketimpangan pendapatan per kapita antar kabupaten/kota yang relatif tinggi dibanding level provinsi dengan tren yang cenderung fluktuatif.

Pada analisis konvergensi statis khususnya analisis indeks IW memberikan informasi bahwa proses konvergensi perekonomian antar kabupaten/kota merupakan proses yang sangat bervariasi antar waktu. Walaupun terlihat ada kecenderungan penurunan dispersi yang konsisten namun indeks IW memperlihatkan proses konvergensi yang pasang surut. Seperti yang terlihat pada tahun 2005 ada kenaikan dari 1,185 menjadi 1,276 (dapat dilihat di lampiran 1) di mana pada periode tersebut harga minyak internasional naik signifikan dari semula USD 35,55 per barel menjadi USD 68,28 per barel yang memicu kenaikan harga bahan bakar dalam negeri sebesar 155 persen. Peningkatan harga minyak dunia tersebut a) mengakibatkan perekonomian di daerah-daerah yang kaya sumber daya alam minyak mengalami booming karena masih banyak kegiatan investasi dan aktivitas ekonomi; dan b) di sisi lain daerah-daerah yang mempunyai kekayaan sumber daya alam minyak mendapat DBH dengan jumlah yang lebih besar sedangkan daerah yang lain tetap.

Gambar 4. Perbandingan Indeks IW dan Standar Deviasi Logaritma Pendapatan Perkapita Periode 2001-2017

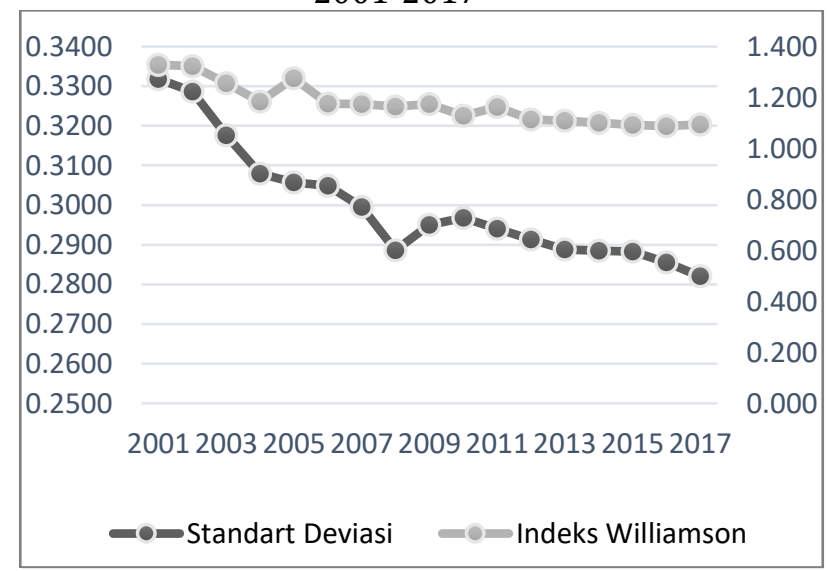

Sumber: BPS (data diolah)

Kemudian, pada tahun 2009 ada kenaikan dari 1,164 menjadi 1,175 (dapat dilihat di lampiran 1) di mana periode tersebut bertepatan dengan badai krisis finansial global yang memberikan efek guncangan pada perekonomian Indonesia. Berdasarkan data dari Bank Indonesia disebutkan bahwa tahun 2009 pertumbuhan ekonomi mengalami perlambatan yaitu sebesar 4,5 persen daripada tahun 2008 sebesar 6,1 persen, nilai tukar rupiah mengalami depresiasi sebesar 30 persen, pasar obligasi dalam negeri mengalami tekanan berupa kenaikan yield secara tajam sebesar 17 persen, terdapat gangguan di pasar keuangan dalam negeri uang mengakibatkan capital flight sekitar 69 tiliun rupiah, dan anjloknya harga komoditas dunia yang memukul kinerja ekspor. Hal tersebut secara tidak langsung memberikan dampak pada penurunan investasi asing sebesar 12 juta USD dibanding tahun 2008 sebesar 17 juta USD. Dengan anjloknya ekspor akibat turunnya harga komoditas dunia serta menurunnya angka investasi asing menyebabkan aktivitas ekonomi di daerah menjadi terganggu.

Dari hasil kedua perhitungan analisis konvergensi statis sebagaimana terlihat pada lampiran 1 yaitu indeks IW dan nilai standar deviasi logaritma pendapatan per kapita antar daerah memberikan bukti yang cukup kuat terhadap hipotesis $\sigma$ konvergen di mana perekonomian antar kabupaten/kota di Indonesia mengalami konvergensi selama periode pelaksanaan otonomi daerah. Dispersi perekonomian antar kabupaten/kota dari periode tahun 2001 sampai dengan 2017 terus mengalami penurunan walaupun terhenti di tahun 2004 dan pada tahun 2005 sedikit mengalami kenaikan. Kemudian dispersi kembali mengalami penurunan dari tahun 2011 sampai tahun 2017. Pergerakan pola tersebut diperlihatkan oleh indeks IW dan nilai standar deviasi ( $\sigma$ konvergen). Pola penurunan disparitas perekonomian antar kabupaten/kota tersebut memberikan sinyal bahwa daerah mampu mengalokasikan faktorfaktor produksi dengan baik serta adanya kesetaraan standar minimum layanan dasar sehingga daerah menemukan keunggulan komparatif mereka sendiri dimana hal tersebut sebagai katalisator dalam mempercepat pertumbuhan ekonomi (Higgins, Levy, and Young, 2006).

\subsection{Analisa Konvergensi Dinamis}

\section{Absolute Convergence}

Pada bagian ini penulis menjabarkan bagaimana tingkat konvergensi absolut yang terjadi antara perekonomian level kabupaten/kota, level kota, dan level kabupaten di Indonesia. Tabel 1 memperlihatkan hasil regresi menggunakan metode robust fixed effect level kabupaten/kota (persamaan 3) nilai koefisien variabel pendapatan per kapita awal (ln_PDBKPT_1) sebesar $-0.0682393\left(\beta_{0}<0\right)$ yang menunjukkan bahwa perekonomian antar kabupaten/kota dalam jangka panjang memperlihatkan terjadinya konvergensi (semakin mengecilnya selisih pertumbuhan antar waktu sehingga perekonomian akan bergerak menuju 
tingkat steady state). Hasil tersebut sejalan dengan hasil dari analisis konvergensi statis ( $\sigma$ konvergen). Tingkat konvergensi absolut yang terjadi antar kabupaten/kota pada periode 20012017 adalah sebesar 7 persen dan waktu yang dibutuhkan untuk menutup setengah dari kesenjangan awal (half-life of convergence) adalah 10 tahun.

\begin{tabular}{|c|c|c|c|}
\hline VARIABLES & $\begin{array}{c}(1) \\
\ln \_ \text {PDBKPT }\end{array}$ & $\begin{array}{c}(2) \\
\ln \_ \text {PDBKPT }\end{array}$ & $\begin{array}{c}(3) \\
\ln \_ \text {PDBKPT }\end{array}$ \\
\hline In_PDBKPT_1 & $\begin{array}{c}-0.0301^{* * *} \\
(0.00739)\end{array}$ & $\begin{array}{c}-0.0780^{* * * *} \\
(0.0107)\end{array}$ & $\begin{array}{c}-0.0682^{* * *} \\
(0.00881)\end{array}$ \\
\hline Constant & $\begin{array}{l}0.138^{* * *} \\
(0.0246)\end{array}$ & $\begin{array}{l}0.263^{* * *} \\
(0.0310)\end{array}$ & $\begin{array}{l}0.241^{* * *} \\
(0.0262)\end{array}$ \\
\hline Observations & 1,460 & 5,920 & 7,380 \\
\hline Number of id & 94 & 411 & 505 \\
\hline adj. R-sq & 0.009 & 0.043 & 0.035 \\
\hline$\lambda$ & $3 \%$ & $8 \%$ & $7 \%$ \\
\hline $\mathbf{T}$ & 23 tahun & 9 tahun & 10 tahun \\
\hline
\end{tabular}

Robust standard errors in parentheses

*** $\mathrm{p}<0.01,{ }^{* *} \mathrm{p}<0.05,{ }^{*} \mathrm{p}<0.1$

Sumber: Output Stata 14 (data diolah)

Hasil regresi level kota (persamaan 1) dimana nilai koefisien variabel pendapatan per kapita awal sebesar $-0.0300675\left(\beta_{0}<0\right)$. Tingkat konvergensi absolut yang terjadi pada level kota pada periode 2001-2017 adalah sebesar 3 persen dan waktu yang dibutuhkan untuk menutup setengah dari kesenjangan awal adalah 23 tahun. Hasil regresi level kabupaten (persamaan 2) dimana nilai koefisien variabel pendapatan per kapita awal sebesar $-0.0780245\left(\beta_{0}<0\right)$. Tingkat konvergensi absolut yang terjadi pada level kabupaten pada periode 2001-2017 adalah sebesar 8 persen dan waktu yang dibutuhkan untuk menutup setengah dari kesenjangan awal adalah 9 tahun.

\section{Conditional Convergence}

Konvergensi kondisional adalah hipotesis yang menyatakan pertumbuhan ekonomi suatu daerah tidak hanya dipengaruhi oleh tingkat pendapatan per kapita awal tetapi perlu disertai syarat karakteristik perekonomian lainnya. Dalam analisis konvergensi kondisional dapat diketahui dampak berbagai variabel eksogen selain tingkat pendapatan per kapita awal terhadap pertumbuhan perekonomian. Variabel eksogen sebagai kontrol dalam penelitian ini menggunakan variabel tenaga kerja (ln_MANPOWER), angka partisipasi pendidikan usia 16-18 tahun (ln_APS), investasi asing (ln_PMA) dan domestik (ln_PMDN). Pemilihan variabel eksogen tersebut dikarenakan variabel investasi, angka partisipasi sekolah, dan tenaga kerja adalah variabel penting yang menjadi determinan pertumbuhan ekonomi suatu daerah. Pengujian konvergensi kondisional menggunakan metode robust fixed effect dimana hasil estimasi persamaan regresi dapat dilihat sebagai berikut:

Tabel 2. Hasil Regresi Konvergensi Kondisional Antar Kabupaten/Kota di Indonesia Periode 2001-2017

\begin{tabular}{lccc}
\hline & $(1)$ & $(2)$ & $(3)$ \\
VARIABLES & $\ln$ PDBKPT & ln_PDBKPT & ln_PDBKPT \\
\hline ln_PDBKPT_1 & $-0.0682^{* * *}$ & $-0.101^{* * *}$ & $-0.117^{* * *}$ \\
& $(0.00881)$ & $(0.0109)$ & $(0.0115)$ \\
ln_MANPOWER & & $-0.0249^{* * *}$ & $-0.0298^{* * *}$ \\
& & $(0.00834)$ & $(0.00863)$ \\
ln_APS & & $0.0693^{* * *}$ & $0.0597^{* * *}$ \\
& & $(0.00900)$ & $(0.00847)$ \\
ln_PMA & & & $0.000752^{* * *}$ \\
& & & $(0.000149)$ \\
ln_PMDN & & & $0.000593^{* * *}$ \\
& & & $(0.000125)$ \\
Constant & $0.241^{* * *}$ & $0.672^{* * *}$ & $0.774^{* * *}$ \\
& $(0.0262)$ & $(0.114)$ & $(0.120)$ \\
Observations & 7,380 & 7,380 & 7,380 \\
adj. R-sq & 0.035 & 0.060 & 0.069 \\
Number of id & 505 & 505 & 505 \\
$\lambda$ & $\mathbf{7 \%}$ & $\mathbf{1 0 \%}$ & $\mathbf{1 2 . 4 \%}$ \\
$\mathbf{T}$ & $\mathbf{1 0}$ tahun & $\mathbf{6}$ tahun & $\mathbf{5 . 5}$ tahun \\
\hline
\end{tabular}

Robust standard errors in parentheses

*** $\mathrm{p}<0.01,{ }^{* *} \mathrm{p}<0.05,{ }^{*} \mathrm{p}<0.1$

Sumber: Output Stata 14 (data diolah)

Tabel 2 memperlihatkan bahwa dengan menambah variabel eksogen yang merupakan determinan pertumbuhan ekonomi terlihat bahwa pada persamaan 2 dan persamaan 3 memberikan dampak terhadap peningkatan kecepatan konvergensi pendapatan per kapita antar daerah di Indonesia pada periode 2001-2017 yang semula dari 7 persen meningkat menjadi 10 persen (persamaan 2) dan 12 persen (persamaan 3). Hal tersebut mengakibatkan berkurangnya waktu yang dibutuhkan untuk menutup setengah dari kesenjangan awal yang semula 10 tahun menjadi 6 tahun (persamaan 2) dan 5,5 tahun (persamaan 3).

Apabila melihat hasil regresi konvergensi kondisional menggunakan metode robust fixed effect di level kota dan di level kabupaten pada tabel 3 menunjukkan bahwa pada level kota (persamaan 1) setelah ditambahkan variabel eksogen terjadi peningkatan kecepatan konvergensi dari semula 3 persen (tabel 1) menjadi 4 persen. Waktu yang dibutuhkan untuk menutup setengah dari kesenjangan awal pada level kota menjadi lebih cepat semula 23 tahun (tabel 1) menjadi 17 tahun. Pada level kabupaten (persamaan 2) setelah ditambahkan variabel eksogen terjadi peningkatan kecepatan konvergensi dari semula 8 persen (lampiran 11) menjadi 15,9 persen. Waktu yang dibutuhkan untuk menutup setengah dari kesenjangan awal pada level kabupaten menjadi lebih cepat semula 
9 tahun (tabel 1) menjadi 4,3 tahun. Hasil konvergensi kondisional sama seperti hasil konvergensi absolut dimana tingkat kecepatan konvergensi level kota lebih lambat dibandingkan level antar kabupaten/kota sedangkan tingkat kecepatan konvergensi level kabupaten lebih baik dibandingkan level antar kabupaten/kota.

Bukti adanya konvergensi yang kuat di level kabupaten sebesar 15 persen menunjukkan bahwa terdapat kesetaraan dalam faktor produktivitas dan daerah yang homogen (sumber daya, topografi, komposisi populasi, dan modal manusia) sehingga konvergensi tingkat pendapatan per kapita antar kabupaten cepat tercapai terlepas dari kondisi awal yang disediakan (Shankar and Shah, 2003). Sedangkan bukti adanya konvergensi yang lemah di level kota sebesar 4 persen menunjukkan penekanan adanya ketergantungan pada kondisi awal, increasing returns to scale, dan eksternalitas investasi sebagai sumber perbedaan dalam faktor produktivitas dan pertumbuhan (Romer, 1990). Bukti empiris tersebut memberikan penegasan bahwa kondisi perekonomian di level kota terdapat ketimpangan dalam penguasaan faktorfaktor produksi yang dominan seperti kawasan industri, pelabuhan, jaringan infrastruktur, tenaga kerja yang terampil.

Tabel 3. Hasil Regresi Konvergensi Kondisional Level Kota dan Level Kabupaten di Indonesia Periode 2001-2017

\begin{tabular}{|c|c|c|c|}
\hline VARIABLES & $\begin{array}{c}(1) \\
\ln \_ \text {PDBKPT }\end{array}$ & $\begin{array}{c}(2) \\
\ln \_ \text {PDBKPT }\end{array}$ & $\begin{array}{c}(3) \\
\ln \_ \text {PDBKPT }\end{array}$ \\
\hline ln_PDBKPT_1 & $\begin{array}{c}-0.0395^{* * *} \\
(0.00987)\end{array}$ & $\begin{array}{c}-0.147^{* * *} \\
(0.0142)\end{array}$ & $\begin{array}{c}-0.117^{* * *} \\
(0.0115)\end{array}$ \\
\hline In_MANPOWER & $\begin{array}{c}-0.0131 \\
(0.00874)\end{array}$ & $\begin{array}{c}-0.0424^{* * *} \\
(0.0110)\end{array}$ & $\begin{array}{c}-0.0298 * * * \\
(0.00863)\end{array}$ \\
\hline ln_APS & $\begin{array}{c}0.0491^{* *} \\
(0.0235)\end{array}$ & $\begin{array}{l}0.0718^{* * *} \\
(0.00969)\end{array}$ & $\begin{array}{c}0.0597 * * * \\
(0.00847)\end{array}$ \\
\hline ln_PMA & $\begin{array}{c}0.000689 * \\
(0.000377)\end{array}$ & $\begin{array}{c}0.000807^{* * *} \\
(0.000168)\end{array}$ & $\begin{array}{c}0.000752^{* * *} \\
(0.000149)\end{array}$ \\
\hline In_PMDN & $\begin{array}{c}-0.000151 \\
(0.000248)\end{array}$ & $\begin{array}{c}0.000790^{* * *} \\
(0.000138)\end{array}$ & $\begin{array}{c}0.000593^{* * *} \\
(0.000125)\end{array}$ \\
\hline Constant & $\begin{array}{c}0.339 * * * \\
(0.117)\end{array}$ & $\begin{array}{c}1.012^{* * *} \\
(0.156)\end{array}$ & $\begin{array}{c}0.774^{* * *} \\
(0.120)\end{array}$ \\
\hline $\begin{array}{l}\text { Observations } \\
\text { Number of id } \\
\text { adj. R-sq } \\
\lambda \\
\mathbf{T}\end{array}$ & $\begin{array}{c}1,460 \\
94 \\
0.016 \\
\mathbf{4 \%} \\
\mathbf{1 7} \text { tahun }\end{array}$ & $\begin{array}{c}5,920 \\
411 \\
0.093 \\
15.9 \% \\
4.3 \text { tahun } \\
\end{array}$ & $\begin{array}{c}\text { 7,380 } \\
505 \\
0.069 \\
\mathbf{1 2 . 4 \%} \\
\mathbf{5 . 5} \text { tahun } \\
\end{array}$ \\
\hline $\begin{array}{l}\text { Robust standarc } \\
*_{* *} \mathrm{p}<0.01,{ }^{* *} \mathrm{p} \\
\text { Sumber: Output }\end{array}$ & $\begin{array}{l}\text { rrors in par } \\
05,{ }^{*} p<0.1 \\
\text { ata } 14 \text { (data }\end{array}$ & $\begin{array}{l}\text { heses } \\
\text { olah) }\end{array}$ & \\
\hline
\end{tabular}

Pada tabel 3 dapat dilihat pengaruh investasi baik asing maupun domestik terhadap pertumbuhan pendapatan per kapita antar kabupaten/kota menunjukkan hubungan yang positif. Investasi di level kota yang menunjukkan pengaruh negatif (investasi PMDN) mengindikasikan bahwa investasi di level kota sudah mengalami kejenuhan sehingga peningkatan investasi tidak berdampak terlalu banyak terhadap peningkatan aktivitas ekonomi. Hal berbeda ditunjukkan oleh investasi di level kabupaten baik investasi PMA maupun PMDN yang memberikan pengaruh positif. Investasi di level kabupaten tidak terlalu padat sehingga peningkatan investasi berdampak pada peningkatan aktivitas perekonomian di level kabupaten. Kondisi tersebut dapat dijelaskan dari kerangka teori pertumbuhan Solow yaitu apabila modal per pekerja $(k)$ meningkat maka output per pekerja akan meningkat $(y)$ tetapi peningkatan modal menyebabkan peningkatan output yang lebih kecil dan semakin kecil (ketika modal per pekerja sudah tinggi, peningkatan lebih lanjut dalam modal per pekerja hanya berdampak kecil pada output per pekerja). Hal tersebut dikarenakan asumsi diminishing return to capital. Pada tahap tertentu, perekonomian tidak mampu menabung dan berinvestasi cukup banyak untuk meningkatkan modal lebih lanjut. Pada tahap tersebut menyebabkan output per pekerja akan berhenti tumbuh. Tingkat tabungan yang lebih tinggi pada suatu perekonomian secara permanen tidak dapat meningkatkan tingkat pertumbuhan output. Dengan demikian, dalam jangka panjang tingkat pertumbuhan output suatu perekonomian tidak bergantung pada tingkat tabungannya tetapi tingkat tabungan dapat mempengaruhi standar hidup (Blanchard, 2017:211).

\section{Conditional Convergence dan Desentralisasi Fiskal}

Hasil pengujian konvergensi kondisional antar kabupaten/kota menggunakan metode robust fixed effect dengan ukuran desentralisasi fiskal dapat dilihat pada lampiran 2. Hasil regresi pada persamaan 1 sampai dengan 6 terlihat indikator desentralisasi fiskal yang mempunyai arah positif terhadap pertumbuhan pendapatan per kapita adalah PAD, belanja kesehatan, dan belanja pendidikan. Sedangkan indikator desentralisasi fiskal yang mempunyai arah negatif terhadap pertumbuhan pendapatan per kapita adalah DBH, dana transfer, dan belanja infrastruktur. Masing-masing indikator desentralisasi fiskal memberikan dampak yang berbeda terhadap kecepatan konvergensi dari semula 7 persen pada tabel 1 (konvergensi absolut) kemudian meningkat menjadi 12 persen pada tabel 2 (konvergensi kondisional tanpa indikator desentralisasi fiskal). Untuk indikator PAD (ln_PAD) memberikan dampak terhadap kecepatan konvergensi sebesar 14 persen, DBH (ln_DBH) sebesar 14 persen, dana transfer (ln_TRANSFER) sebesar 12 persen, belanja kesehatan (lag_KSHT) sebesar 14 persen, belanja pendidikan (lag_PDDK) sebesar 13 persen, dan belanja infrastruktur (lag_INFRA) sebesar 13 persen. Lama waktu yang dibutuhkan untuk 
menutup setengah dari kesenjangan awal untuk semua indikator desentralisasi fiskal relatif sama di kisaran 5 tahun.

Jika dilihat pada persamaan 7 lampiran 2 hasil regresi yang menggunakan indikator desentralisasi fiskal secara bersamaan tidak menunjukkan adanya perbedaan hasil jika dibandingkan dengan persamaan 1 sampai dengan persamaan 6 hanya indikator dana transfer yang berubah menjadi positif. Pada persamaan 7 terlihat indikator desentralisasi fiskal memberikan dampak terhadap kecepatan konvergensi pendapatan per kapita antar kabupaten/kota sebesar 18 persen. Lama waktu yang dibutuhkan untuk menutup setengah dari kesenjangan awal meningkat menjadi 3,8 tahun.

Berikut dijabarkan bagaimana dampak desentralisasi fiskal terhadap kecepatan konvergensi pada level kota dan level kabupaten pada periode 2001-2017. Pengujian konvergensi kondisional menggunakan indikator desentralisasi fiskal pada level kota dan level kabupaten dengan metode robust fixed effect dimana hasil estimasi persamaan regresi dapat dilihat pada tabel 4 . Pada persamaan 1 tabel 4 diketahui bahwa dampak desentralisasi fiskal pada level kota terhadap kecepatan konvergensi pendapatan per kapita hanya sebesar 11 persen, nilai tersebut lebih rendah dibandingkan pada level kabupaten/kota (persamaan 3) yaitu sebesar 18 persen. Sedangkan lama waktu yang dibutuhkan untuk menutup setengah dari kesenjangan awal yaitu 6,1 tahun dan waktu tersebut lebih lambat daripada level kabupaten/kota (persamaan 3) yaitu 3,8 tahun. Secara keseluruhan dampak desentralisasi fiskal pada level kota terhadap kecepatan konvergensi mempunyai tingkat lebih rendah dibandingkan pada level kabupaten/kota.

Pada persamaan 2 tabel 4 diketahui bahwa dampak desentralisasi fiskal pada level kabupaten terhadap kecepatan konvergensi pendapatan per kapita adalah sebesar 20 persen, nilai tersebut sedikit lebih tinggi dibandingkan pada level kabupaten/kota (persamaan 3) yaitu sebesar 18 persen. Sedangkan lama waktu yang dibutuhkan untuk menutup setengah dari kesenjangan awal yaitu 3,4 tahun dan waktu tersebut sedikit lebih cepat dibandingkan level kabupaten/kota (persamaan 3) yaitu 3,8 tahun. Secara keseluruhan jika dibandingkan antara dampak desentralisasi fiskal pada level kabupaten dengan level kota terhadap kecepatan konvergensi terdapat selisih yang cukup besar sekitar 9 persen. Dampak desentralisasi fiskal pada level kabupaten terhadap konvergensi pendapatan per kapita mempunyai kecepatan lebih tinggi daripada level kota.
Tabel 4. Hasil Regresi Konvergensi

Kondisional Menggunakan Indikator Desentralisasi Fiskal di Level Kota, Level Kabupaten, dan Level Kabupaten/Kota di Indonesia Periode 2001-2017

\begin{tabular}{|c|c|c|c|}
\hline VARIABLES & $\begin{array}{c}(1) \\
\text { ln_PDBKPT }\end{array}$ & $\begin{array}{c}(2) \\
\ln \_ \text {PDBKPT }\end{array}$ & $\begin{array}{c}(3) \\
\ln \_ \text {PDBKPT }\end{array}$ \\
\hline ln_PDBKPT_1 & $\begin{array}{c}-0.108^{* * *} \\
(0.0189)\end{array}$ & $\begin{array}{c}-0.183^{* * *} \\
(0.0157)\end{array}$ & $\begin{array}{c}-0.165^{* * *} \\
(0.0136)\end{array}$ \\
\hline ln_PAD & $\begin{array}{l}0.0402^{* * *} \\
(0.00700)\end{array}$ & $\begin{array}{l}0.0189 * * * \\
(0.00379)\end{array}$ & $\begin{array}{l}0.0229^{* * *} \\
(0.00348)\end{array}$ \\
\hline ln_DBH & $\begin{array}{c}-0.0121^{* * *} \\
(0.00401)\end{array}$ & $\begin{array}{c}-0.0146^{* * *} \\
(0.00378)\end{array}$ & $\begin{array}{c}-0.0160^{* * *} \\
(0.00340)\end{array}$ \\
\hline In_TRANSFER & $\begin{array}{c}5.28 \mathrm{e}-05 \\
(0.00124)\end{array}$ & $\begin{array}{c}0.00753 \\
(0.00826)\end{array}$ & $\begin{array}{c}0.00134 \\
(0.00264)\end{array}$ \\
\hline lag_KSHT & $\begin{array}{l}0.0186^{* * *} \\
(0.00480)\end{array}$ & $\begin{array}{l}0.0139 * * * \\
(0.00238)\end{array}$ & $\begin{array}{l}0.0149 * * * \\
(0.00217)\end{array}$ \\
\hline lag_PDDK & $\begin{array}{c}-0.00385 \\
(0.00308)\end{array}$ & $\begin{array}{c}0.00466^{* * *} \\
(0.00132)\end{array}$ & $\begin{array}{c}0.00312^{* * *} \\
(0.00120)\end{array}$ \\
\hline lag_INFRA & $\begin{array}{c}-0.00466 \\
(0.00389)\end{array}$ & $\begin{array}{c}-0.00922^{* * *} \\
(0.00178)\end{array}$ & $\begin{array}{c}-0.00856^{* * *} \\
(0.00164)\end{array}$ \\
\hline In_MANPOWER & $\begin{array}{c}-0.0635^{* * *} \\
(0.0108)\end{array}$ & $\begin{array}{c}-0.0568 * * * \\
(0.0132)\end{array}$ & $\begin{array}{c}-0.0535^{* * *} \\
(0.0108)\end{array}$ \\
\hline ln_APS & $\begin{array}{c}0.0114 \\
(0.0268)\end{array}$ & $\begin{array}{l}0.0453^{* * *} \\
(0.00713)\end{array}$ & $\begin{array}{l}0.0342^{* * *} \\
(0.00624)\end{array}$ \\
\hline ln_PMA & $\begin{array}{c}0.000355 \\
(0.000382)\end{array}$ & $\begin{array}{c}0.000522^{* * *} \\
(0.000157)\end{array}$ & $\begin{array}{c}0.000445^{* * *} \\
(0.000143)\end{array}$ \\
\hline ln_PMDN & $\begin{array}{c}-0.000198 \\
(0.000251)\end{array}$ & $\begin{array}{c}0.000696^{* * *} \\
(0.000143)\end{array}$ & $\begin{array}{c}0.000512^{* * *} \\
(0.000127)\end{array}$ \\
\hline Constant & $\begin{array}{c}1.536^{* * *} \\
(0.229)\end{array}$ & $\begin{array}{c}1.482^{* * *} \\
(0.229)\end{array}$ & $\begin{array}{c}1.371^{* * *} \\
(0.171)\end{array}$ \\
\hline Observations & 1,366 & 5,509 & 6,875 \\
\hline adj. R-sq & 94 & 411 & 0.108 \\
\hline Number of id & 0.073 & 0.124 & 505 \\
\hline$\lambda$ & $11,4 \%$ & $20,2 \%$ & $18,0 \%$ \\
\hline $\mathbf{T}$ & 6,1 tahun & 3,4 tahun & 3,8 tahun \\
\hline
\end{tabular}

PAD memberikan pengaruh positif pada perekonomian daerah karena pemerintah kabupaten/kota memiliki kendali yang kuat terhadap PAD sehingga mampu mempengaruhi kinerja perekonomian (Ebel and Yilmaz, 2002). Tingkat kendali pemerintah daerah terhadap PAD dapat dijelaskan sebagai berikut:

- Penerapan batas maksimal tarif pajak dan retribusi daerah yang diberlakukan oleh pemerintah daerah selama otonomi daerah sebagaimana diamanatkan oleh UndangUndang Nomor 28 Tahun 2009 tentang Pajak Daerah dan Retribusi Daerah tidak mendistorsi perekonomian daerah. Dengan demikian, tarif dan basis pajak dan retribusi daerah justru meningkatkan aktivitas perekonomian di daerah

- Instrumen jenis pajak dan retribusi daerah yang menjadi kewenangan pemerintah daerah dalam UU Nomor 28 Tahun 2009 sejauh ini tidak menimbulkan pajak berganda (double taxation), artinya pemerintah pusat telah sesuai dalam menetapkan jenis-jenis instrumen pajak dan retribusi daerah yang 
dilimpahkan dan menjadi kewenangan penuh pemerintah daerah.

DBH yang memberikan pengaruh negatif pada perekonomian daerah mengindikasikan bahwa transfer DBH yang bersumber dari bagi hasil pajak dan bagi hasil sumber daya alam dari pusat ke daerah belum dapat menghasilkan sumber-sumber pertumbuhan ekonomi baru di daerah. DBH bersifat block grant yang penggunaannya menjadi kewenangan penuh dari pemerintah daerah. Penggunaan DBH juga tidak di-earmarked untuk membiayai belanja tertentu, sehingga pemerintah pusat tidak dapat mengontrol pemanfaatan DBH saat ini, akibatnya terdapat potensi pemanfaatan DBH yang digunakan untuk belanja tidak langsung lebih besar daripada belanja langsung (berdasarkan data histori realisasi APBD Direktorat Jenderal Perimbangan Keuangan Tahun 2017 untuk belanja pegawai sebesar 38 persen, belanja barang sebesar 23 persen, dan belanja modal sebesar 20 persen). Pengalokasian jumlah belanja tidak langsung yang lebih besar dari belanja langsung oleh pemerintah daerah memberikan konsekuensi bahwa belanja tersebut kurang memberikan stimulus terhadap perekonomian yang memperlancar arus barang dan manusia. Padahal untuk menciptakan sumber-sumber pertumbuhan ekonomi baru sebaiknya pemerintah daerah harus mengurangi alokasi belanja tidak produktif dan berusaha menjaga agar pemerintah sendiri tidak menjadi sumber utama misalokasi belanja sehingga mampu mempercepat pertumbuhan ekonomi (Tanzi, 1995). Selain ketimpangan alokasi antara belanja tidak langsung dan belanja langsung, pemerintah daerah juga menghadapi permasalahan terkait penyerapan anggaran belanja. Salah satu indikator untuk melihat rendahnya penyerapan belanja daerah adalah melalui data tingginya besaran Sisa Lebih Pembiayaan Anggaran Tahun Berkenaan
(SILPA), sebagaimana terlihat pada gambar 5 , di mana rata-rata sebagian besar daerah mempunyai SILPA lebih dari 10 persen. SILPA yang tinggi mengindikasikan rendahnya kemampuan daerah dalam melakukan belanja yang efektif. Sudah menjadi rahasia umum bahwa dana SILPA dari pemerintah daerah yang disimpan pada bank pembangunan daerah dapat digunakan sebagai penempatan pada Sertifikat Bank Indonesia (SBI). SILPA yang ditempatkan pemerintah daerah pada SBI menyebabkan dana daerah tersebut akan kembali lagi ke pusat sehingga infrastruktur di daerah tidak terbangun. Padahal pemerintah pusat memberikan dana transfer kepada pemerintah daerah untuk akselerasi pembangunan daerah.

Dana transfer yang memberikan pengaruh positif pada perekonomian daerah mengindikasikan bahwa DAU yang diberikan oleh pusat kepada daerah bertujuan untuk mengurangi disparitas kapasitas fiskal antar daerah. Dengan kapasitas fiskal yang sesuai kebutuhan fiskal di masing-masing daerah diharapkan dapat tercipta keseragaman standar pelayanan publik antar daerah. Adapun DAK sebagai dana transfer dari pusat kepada daerah cenderung digunakan membiayai kegiatan dan program yang sudah ditentukan di daerah yang biasanya berhubungan dengan tercapainya prioritas nasional. Penyebab dana transfer mempunyai arah positif tetapi tidak signifikan terhadap pertumbuhan pendapatan per kapita di daerah yaitu karena penggunaan DAU yang sebagian besar untuk belanja tidak langsung seperti belanja gaji pegawai, sehingga peran DAU yang diharapkan menjadi katalisator pertumbuhan perekonomian daerah menjadi kurang maksimal. Kemudian DAK sebagai conditional transfer yang diberikan pusat kepada daerah, biasanya digunakan untuk membiayai kegiatan produktif, telah sesuai dengan preferensi dan kebutuhan masyarakat di daerah.

Gambar 5. Persentase SILPA Terhadap Total Belanja Daerah Periode 2007-2010-2017

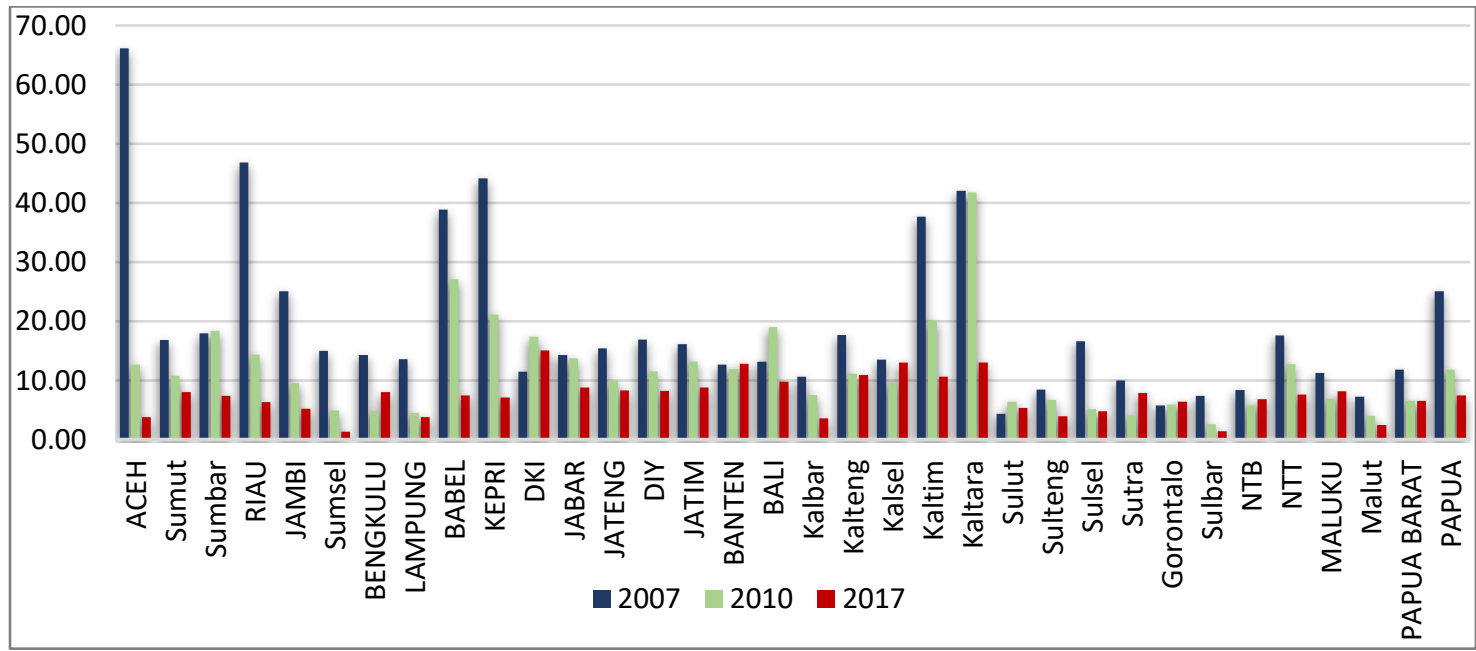

Sumber: Kementerian Keuangan (data diolah) 
Belanja sektor pendidikan dan kesehatan memberikan pengaruh yang positif terhadap perekonomian daerah. Hal tersebut menggambarkan bahwa kebijakan pemerintah daerah dalam mengelola anggaran sektor kesehatan dan pendidikan melalui program dan kegiatan sebagai bentuk pelayanan publik mampu memenuhi kebutuhan dan preferensi masyarakat di daerah. Peran pemerintah daerah sangat penting dan stategis dalam menyediakan akses bagi masyarakat untuk menikmati fasilitas publik di bidang kesehatan dan pendidikan. Semakin mudah dan murah masyarakat dalam mengakses fasilitas publik di bidang kesehatan dan pendidikan, maka berdampak pada kesejahteraan masyarakat tersebut. Sektor kesehatan memainkan fungsi vital terkait peningkatan produktivitas yang berdampak pada kesejahteraan. Sedangkan sektor pendidikan memainkan fungsi vital tentang bagaimana suatu bangsa mampu menguasai perkembangan teknologi dan informasi yang berdampak pada peningkatan kapasitas sehingga tercapainya pertumbuhan ekonomi. Kedua sektor tersebut membentuk modal sumber daya manusia yang berkompeten dan sanggup memanfaatkan modal fisik menjadi lebih produktif sehingga berdampak pada peningkatan output.

Di sisi lain, belanja sektor infrastruktur justru memberikan pengaruh negatif pada perekonomian daerah. Bukti empiris tersebut mengindikasikan bahwa sebagian besar pembangunan infrastruktur di daerah tidak optimal memberi dampak langsung terhadap aktivitas perekonomian daerah (berdasarkan data BPS tentang Statistik Infrastruktur Indonesia 2019 disebutkan untuk infrastruktur pendidikan terdapat 8 provinsi di mana dalam suatu kecamatan belum terdapat fasilitas setingkat SMP dan masih terdapat 13 persen kabupaten/kota yang tidak memiliki perguruan tinggi; untuk infrastruktur kesehatan terdapat 3 persen kabupaten/kota di Indonesia yang belum memiliki rumah sakit; untuk infrastruktur ekonomi terdapat 40 persen kabupaten/kota yang belum memiliki pasar dengan bangunan permanen, hanya 14 persen desa memiliki minimal 1 unit embung, 35 persen desa tidak memiliki unit usaha BUMDes). Hal tersebut dapat disebabkan karena pemilihan jenis infrastruktur atau lokasi infrastruktur tidak sesuai dengan kebutuhan dan prioritas masyarakat di daerah. Padahal salah satu faktor yang membantu daerah untuk mengejar ketertinggalan perekonomian adalah adanya kemudahan akses terhadap infrastruktur yang menjadi prioritas dan sesuai dengan kebutuhan masyarakat dalam aktivitas ekonomi.

Belanja sektor infrastruktur terbagi menjadi dua pengeluaran yaitu pengeluaran untuk membangun infrastruktur baru dan pengeluaran untuk perawatan infrastruktur yang sudah ada. Besaran belanja sektor infrastruktur di daerah sangatlah terbatas sehingga menjadi permasalahan tersendiri bagi pemerintah daerah. Apabila pemerintah daerah fokus untuk membangun infrastruktur baru maka alokasi pengeluaran untuk perawatan infrastruktur yang sudah ada akan berkurang, sehingga berdampak pada manfaat dan masa pakai yang harusnya dapat diperoleh dari infrastruktur tersebut. Selain itu, ada lag waktu untuk merasakan adanya manfaat dari pembangunan infrastruktur dengan demikian pembangunan infrastruktur dapat mempengaruhi perekonomian dalam jangka panjang. Sebaliknya, jika pemerintah daerah fokus terhadap pengeluaran untuk perawatan infrastruktur yang sudah ada maka daerah mengalami kekurangan infrastruktur yang memadai. Dengan demikian berdampak pada keterbatasan konektivitas yang menghambat kelancaran arus barang dan manusia di daerah. Tentu kedua hal tersebut diatas mempengaruhi kinerja pertumbuhan ekonomi di daerah.

\section{KESIMPULAN DAN SARAN}

Berdasarkan analisis konvergensi statis, hasil studi ini mencatat bahwa selama periode otonomi daerah sejak tahun 2001 sampai dengan 2017 terdapat penurunan dalam disparitas pendapatan per kapita antar kabupaten/kota. Hal tersebut ditunjukkan dari hasil perhitungan indeks IW yang memperlihatkan adanya kecenderungan penurunan dispersi pendapatan per kapita yang konsisten dari tahun ke tahun. Dari hasil indeks IW tersebut memberikan bukti cukup kuat terhadap hipotesis $\sigma$ konvergen di mana perekonomian antar kabupaten/kota di Indonesia mengalami konvergensi selama periode otonomi daerah.

Sedangkan berdasarkan analisis konvergensi dinamis, hasil studi ini mencatat bahwa perekonomian antar kabupaten/kota di Indonesia selama periode otonomi daerah terjadi konvergensi. Hal tersebut dibuktikan dalam pengujian konvergensi absolut dan konvergensi kondisional. Diketahui bahwa tingkat konvergensi absolut adalah sebesar 7 persen, tingkat konvergensi kondisional dengan memperhitungkan variabel penjelas tanpa indikator desentralisasi fiskal adalah sebesar 12 persen, dan tingkat konvergensi kondisional yang memperhitungkan variabel penjelas dengan indikator desentralisasi fiskal adalah sebesar 18 persen. Sedangkan waktu yang dibutuhkan untuk menutup setengah dari kesenjangan awal (half-life of convergence) untuk konvergensi absolut adalah 10 tahun, konvergensi kondisional tanpa indikator 
desentralisasi fiskal adalah 5,5 tahun, dan konvergensi kondisional dengan indikator desentralisasi fiskal adalah 3,8 tahun.

Berdasarkan analisis konvergensi dinamis diketahui bahwa konvergensi pendapatan per kapita di level kabupaten lebih baik dari level kota. Desentralisasi fiskal mampu membantu kabupaten mempercepat tingkat konvergensi sebesar 20 persen sedangkan di level kota hanya sebesar 11 persen. Indikator desentralisasi fiskal yang berdampak signifikan terhadap pertumbuhan perekonomian di level kabupaten adalah dari sisi belanja terutama belanja sektor pendidikan dan kesehatan.

\section{IMPLIKASI DAN KETERBATASAN}

\subsection{Implikasi}

Dari hasil analisis diketahui bahwa PAD berpengaruh positif dan signifikan terhadap pertumbuhan ekonomi dan kecepatan konvergensi. Dengan demikian perlu menjadi perhatian dari pemerintah pusat untuk terus meningkatkan kapasitas fiskal daerah terutama penguatan sumber-sumber pendapatan daerah yang berasal dari pajak dan retribusi daerah (empowering local tax). Dengan adanya ketergantungan pemerintah daerah terhadap PAD secara otomatis menyediakan insentif dan kapasitas bagi daerah untuk mengadopsi kebijakan yang berorientasi pada kebutuhan dan preferensi masyarakat. Selain itu, peningkatan kapasitas fiskal daerah memberikan daerah lebih banyak ruang fiskal untuk pembangunan yang berorientasi pada kepentingan publik. Dengan demikian, semakin banyak ruang fiskal bagi daerah untuk pembangunan maka semakin mempercepat tingkat konvergensi perekonomian antar daerah

Hasil penelitian ini menunjukan bahwa dana transfer memiliki pengaruh positif namun tidak signifikan terhadap perekonomian daerah. Bukti empiris tersebut mengindikasikan bahwa dana transfer dari pusat ke daerah memberikan manfaat yang kurang maksimal terhadap pertumbuhan pendapatan per kapita di daerah. Dengan demikian perlu adanya penguatan pemanfaatan dana transfer melalui perbaikan tata kelola (governance) pemanfaatan dana transfer yang mendorong kompetensi dan inovasi daerah sehingga belanja daerah lebih mengacu pada prinsip value for money. Untuk meningkatkan kompetensi dan inovasi daerah yang berdampak pada efisiensi alokasi sumber daya sebaiknya pemerintah pusat perlu meningkatkan dana transfer yang bersifat stimulus pemerintah daerah untuk terus berkompetisi dan berinovasi.
Dengan adanya perbedaan kapasitas fiskal antar daerah dimana apabila daerah hanya mengandalkan dana transfer untuk mempercepat konvergensi pendapatan per kapita antar daerah maka hal tersebut tidaklah memungkinkan. Dengan demikian, proses percepatan konvergensi pendapatan per kapita antar daerah membutuhkan peran intervensi dari pemerintah pusat. Intervensi tersebut dapat dilakukan dengan cara meningkatkan jumlah pembiayaan dari Kementerian Negara/Lembaga (sektoral) khususnya untuk pembiayaan pembangunan daerah-daerah yang mempunyai kapasitas fiskal rendah dan hanya bergantung pada dana transfer, di mana sampai dengan saat ini intervensi pembiayaan dari Kementerian Negara/Lembaga (sektoral) tersebut sangat membantu daerah dalam penyediaan infrastruktur baru seperti pembangunan jalan, jembatan, bandara baru, revitalisasi pelabuhan, serta sarana pendidikan dan kesehatan.

\subsection{Keterbatasan}

Fokus penelitian ini hanya memberikan bukti secara empiris bahwa pelaksanaan otonomi daerah melalui pemberian kewenangan fiskal kepada daerah, yang efektif dimulai sejak tahun 2001, mempunyai pengaruh dalam mempercepat tingkat konvergensi perekonomian antar daerah. Penggunaan indikator desentralisasi fiskal dalam penelitian ini hanya menggunakan ukuran fiskal dari sisi penerimaan dan pengeluaran daerah. Desentralisasi fiskal adalah produk dari sebuah proses politik, kelembagaan, dan sejarah yang melatarbelakangi pembagian kewenangan antar tingkatan pemerintahan. Dengan demikian pada penelitian selanjutnya perlu dipertimbangkan adanya tambahan variabel indikator desentralisasi administrasi dan desentralisasi politik dalam model. Sebaiknya model juga perlu dimasukkan beberapa variabel kontrol yang menjadi determinan pertumbuhan ekonomi seperti nilai perdagangan antar daerah, inflasi, tabungan, dan penyaluran kredit perbankan ke masyarakat. Untuk melihat dampak indikator desentralisasi fiskal terhadap tingkat konvergensi pendapatan per kapita antar daerah secara lebih luas lagi sebaiknya perlu menambah periode waktu penelitian sebelum pelaksanaan otonomi daerah di tahun 2001.

\section{DAFTAR PUSTAKA}

Abramovitz, M. (1986). Catching up, forging ahead, and falling behind. The Journal of Economic History, 46(2), 385-406.

Akai, N., \& Sakata, M. (2002). Fiscal decentralisation contributes to economic growth: evidence from state-level crosssection data for the United States. Journal of 
Urban Economics, 52, 93-108.

Aritenang, A. F. (2010). The impact of government budget shifts to regional disparities in Indonesia: before and after decentralisation. Munich Personal RePEc Archive Paper, (25243). Retrieved from http://mpra.ub.unimuenchen.de/25243/.

Bahl, R. (1999). Fiscal Decentralisation as development policy. Public Budgeting and Finance, 19(2), 59-75. https://doi.org/10.1046/j.02751100.1999.01163.x.

Bahl, R. \& Linn, J. (1994). Fiscal decentralisation and intergovernmental transfers in less developed countries. Publius, 24(1), 1-19. Retrieved. from https://www.jstor.org/stabel/3330701.

Badan Pusat Statistik. (2019). Statistik Infrastruktur Indonesia 2019. Jakarta: Badan Pusat Statistik.

Barro, R. J., \& Sala-i-martin, X. (1992). Convergence. Journal of Political Economy, 100(2), 223-251. Retrieved from http://www.jstor.org/stabel/2138606.

Barro, R. J. \& Sala-i-Martin, X. (1990). Economic growth and convergence across The United States. National Bureau of Economic Research Working Paper Series, 3419(August).

Barro, R. J. \& Sala-i-Martin, X. (2004). Economic Growth (second). Cambridge, Massachusetts: The MIT Press. https://doi.org/10.1016/S01640704(96)80041-3.

Bartolini, D., Stossberg, S. \& Blöchliger, H. (2016). Fiscal decentralisation and regional disparities. OECD Economics Department Working Paper, (1330). Retrieved from https://dx.doi.org/10.1787/5jlpq7v3j237en.

Bird, R.M. \& Vaillancourt, F. (1998). Fiscal decentralisation in development countries. London: Cambridge University Press.

Blanchard, O. (2017). Macroeconomics. (A. D'Ambrosio, Ed.) (7th ed.). Boston: Pearson Education. Retrieved from http://lccn.loc.gov/2016001144.

Cherodian, R. \& Thirlwall, A. P. (2015) 'Regional disparities in per capita income in India: convergence or divergence?', Journal of Post Keynesian Economics. 2015, 37(3), pp. 384407. doi: 10.1080/01603477.2015.1000109.

Davoodi, H., \& Zou, H. (1998). Fiscal Decentralisation and Economic Growth: A Cross-Country Study. Journal of Urban Economics, 43, 244-257.

Devarajan, S., Swaroop, V., \& Zou, H. F. (1996). The composition of public expenditure and economic growth. Journal of Monetary Economics, 37(2), 313-344. https://doi.org/10.1016/S0304-
3932(96)90039-2.

Ebel, R. D. \& Yilmaz, S. (2002). On the Measurement and Impact of Fiscal Decentralisation. World Bank Policy Research Working Paper, 1-27.

Garcia, J. G. \& Soelistianingsih, L. (1998). Why do differences in provincial incomes persist in Indonesia? Bulletin of Indonesian Economic Studies, $\quad 34(1), \quad 95-120$. https://doi.org/10.1080/000749198123313 37290.

Higgins, M. J., Levy, D., \& Young, A. T. (2006). Growth and convergence across the US .: Evidence from County-Level Data. The Review of Economics and Statistics, 88(4), 671-681.

Hofman, B., \& Kaiser, K. (2002). The making of the 'Big Bang'and its aftermath: a political economy perspective. World Bank Regional Public Expenditure Review.

Iimi, A. (2005). Decentralisation and economic growth revisited: an empirical note. Journal of Urban Economics, 57, 449-461. https://doi.org/10.1016/j.jue.2004.12.007.

Islam, N. (1995). Growth empirics: a panel data approach. The Quarterly Journal of Economics, 110(4), 1127-1170. Retrieved from https://www.jstor.org/stabel/2946651.

Mankiw, N. G., Romer, D., \& Weil, D. N. (1992). A Contribution to the Empirics of Economic Growth. The Quarterly Journal of Economics, 107(2), 407-437. Retrieved from https://www.jstor.org/stabel/2118477.

Meloche, J. P., Vaillancourt, F., \& Yilmaz, S. (2004). Decentralisation or fiscal autonomy? what does really matter? effects on growth and public sector size in European Transition Countries. World Bank Policy Research Working Paper, 3254.

Musgrave, Richard A. (1991). Keuangan negara: dalam teori dan praktek. Jakarta: Erlangga.

Oates, W.E. (1972). Fiscal federalism. New York: Harcourt Brace Jovanovich.

Ogawa, H., \& Yakita, S. (2009). Equalisation Transfers , Fiscal Decentralisation, and Economic Growth. FinanzArchiv: Public Finance Analysis, 65(1),122-140. https://doi.org/10.1628/001522109X44419 8

Resosudarmo, B. P. ., and Vidyattama, Y. (2006). Regional Income Disparity in Indonesia: A Panel Data Analysis. ASEAN Economic Bulletin, 23(1), 31-44. https://doi.org/10.1355/ae23-lc

Romer, P. M. (1990). Human Capital and Growth: Theory and Evidence. Carnegie-Rochester Conference Series on Public Policy, 32, 251286. Retrieved from https://doi.org/10.1016/01672231(90)90028-J.

Sato, M. (2004). Fiscal decentralisation in Asia 


revisited: a $\begin{gathered}\text { theoretical } \\ \text { International } \\ \text { Symposium }\end{gathered}$ on Fiscal
$\begin{aligned} & \text { Decentralisation in Asia } \\ & \text { Contribution Paper, 1-35. }\end{aligned}$

Shankar, R., \& Shah, A. (2003). Bridging the economic divide within countries: a scorecard on the performance of regional policies in reducing regional income disparities. World Development, 31(8), 14211441. https://doi.org/10.1016/S0305750X(03)00098-6.

Tanzi, V. (1995). Fiscal federalism and decentralisation: A review of some efficiency and macroeconomic aspects. In CDC: World Bank (pp. 295-316). Washington^ ${ }^{\wedge}$ D.

Tiebout, C. M. . (1956). A pure theory of local expenditures. Journal of Political Economy, 64(5), 416-424. Retrieved from https://www.jstor.org/stabel/1826343.

Turganbayev, Y. (2016). Regional convergence in Kazakhstan. Post-Communist Economies. Routledge, 28(3), pp. 314-334. doi: 10.1080/14631377.2016.1204745.

Vidyattama, Y. (2013). Regional convergence and the role of the neighbourhood effect in decentralised Indonesia. Bulletin of Indonesian Economic Studies, 49(2), 193-211. https://doi.org/10.1080/00074918.2013.80 9841.

Wibisono, Y. (2003). Konvergensi di Indonesia: Beberapa temuan awal dan implikasinya. Economics and Finance in Indonesia, 51(1), 53-82.

Woller, G. M., \& Phillips, K. (1998). Fiscal decentralisation and IDC economic growth: An empirical investigation. The Journal of Development Studies, 34(4), 139-148. https://doi.org/10.1080/002203898084225 32.

Yushkov, A. (2015). Fiscal decentralisation and regional economic growth : Theory, empirics , and the Russian experience. Russian Journal of Economics. Non-profit partnership Voprosy Ekonomiki, 1(4), 404-418. doi: 10.1016/j.ruje.2016.02.004. 
Lampiran 1. Analisa Statis Konvergensi Pendapatan Perkapita Indonesia Tahun 2001-2017

\begin{tabular}{|l|l|l|}
\hline Tahun & Standart Deviasi & Indeks Williamson \\
\hline $\mathbf{2 0 0 1}$ & 0,3318 & 1,329 \\
\hline $\mathbf{2 0 0 2}$ & 0,3287 & 1,323 \\
\hline $\mathbf{2 0 0 3}$ & 0,3176 & 1,256 \\
\hline $\mathbf{2 0 0 4}$ & 0,3080 & 1,185 \\
\hline $\mathbf{2 0 0 5}$ & 0,3057 & 1,276 \\
\hline $\mathbf{2 0 0 6}$ & 0,3049 & 1,176 \\
\hline $\mathbf{2 0 0 7}$ & 0,2995 & 1,174 \\
\hline $\mathbf{2 0 0 8}$ & 0,2886 & 1,164 \\
\hline $\mathbf{2 0 0 9}$ & 0,2950 & 1,175 \\
\hline $\mathbf{2 0 1 0}$ & 0,2968 & 1,129 \\
\hline $\mathbf{2 0 1 1}$ & 0,2940 & 1,162 \\
\hline $\mathbf{2 0 1 2}$ & 0,2913 & 1,115 \\
\hline $\mathbf{2 0 1 3}$ & 0,2888 & 1,109 \\
\hline $\mathbf{2 0 1 4}$ & 0,2885 & 1,101 \\
\hline $\mathbf{2 0 1 5}$ & 0,2883 & 1,093 \\
\hline $\mathbf{2 0 1 6}$ & 0,2856 & 1,088 \\
\hline $\mathbf{2 0 1 7}$ & 0,2820 & 1,094 \\
\hline Sumber & & \\
\hline
\end{tabular}

Sumber: BPS (data diolah) 
18

\section{Lampiran 2. Hasil Regresi Konvergensi Kondisional Menggunakan Indikator Desentralisasi Fiskal Antar Kabupaten/Kota di Indonesia Periode 2001-2017}

\begin{tabular}{|c|c|c|c|c|c|c|c|}
\hline VARIABLES & $\begin{array}{c}(1) \\
\ln \_ \text {PDBKРТ }\end{array}$ & $\begin{array}{c}(2) \\
\ln \_ \text {PDBKPT }\end{array}$ & $\begin{array}{c}(3) \\
\ln \_ \text {PDBKPT }\end{array}$ & $\begin{array}{c}(4) \\
\ln \_ \text {PDBKPT }\end{array}$ & $\begin{array}{c}(5) \\
\ln \_ \text {PDBKPT }\end{array}$ & $\begin{array}{c}\text { (6) } \\
\ln \_ \text {PDBKPT }\end{array}$ & $\begin{array}{c}(7) \\
\ln \_ \text {PDBKРТ }\end{array}$ \\
\hline ln_PDBKPT_1 & $\begin{array}{c}-0.134^{* * *} \\
(0.0126)\end{array}$ & $\begin{array}{c}-0.137^{* * *} \\
(0.0134)\end{array}$ & $\begin{array}{l}-0.121^{* * *} \\
(0.0124)\end{array}$ & $\begin{array}{c}-0.132^{* * *} \\
(0.0125)\end{array}$ & $\begin{array}{l}-0.124^{* * *} \\
(0.0124)\end{array}$ & $\begin{array}{c}-0.122^{* * *} \\
(0.0125)\end{array}$ & $\begin{array}{c}-0.165^{* * *} \\
(0.0136)\end{array}$ \\
\hline ln_PAD & $\begin{array}{l}0.0212^{* * *} \\
(0.00340)\end{array}$ & & & & & & $\begin{array}{l}0.0229^{* * *} \\
(0.00348)\end{array}$ \\
\hline ln_DBH & & $\begin{array}{c}-0.0207^{* * *} \\
(0.00353)\end{array}$ & & & & & $\begin{array}{l}-0.0160^{* * *} \\
(0.00340)\end{array}$ \\
\hline In_TRANSFER & & & $\begin{array}{l}-3.14 \mathrm{e}-06 \\
(0.00183)\end{array}$ & & & & $\begin{array}{c}0.00134 \\
(0.00264)\end{array}$ \\
\hline lag_KSHT & & & & $\begin{array}{l}0.0122^{* * *} \\
(0.00134)\end{array}$ & & & $\begin{array}{l}0.0149 * * * \\
(0.00217)\end{array}$ \\
\hline lag_PDDK & & & & & $\begin{array}{l}0.00553^{* * *} \\
(0.000667)\end{array}$ & & $\begin{array}{c}0.00312^{* * *} \\
(0.00120)\end{array}$ \\
\hline lag_INFRA & & & & & & $\begin{array}{c}-0.00171 \\
(0.00122)\end{array}$ & $\begin{array}{c}-0.00856^{* * *} \\
(0.00164)\end{array}$ \\
\hline In_MANPOWER & $\begin{array}{c}-0.0418^{* * *} \\
(0.0102)\end{array}$ & $\begin{array}{c}-0.0363^{* * *} \\
(0.00980)\end{array}$ & $\begin{array}{c}-0.0335^{* * *} \\
(0.00969)\end{array}$ & $\begin{array}{c}-0.0399 * * * \\
(0.00992)\end{array}$ & $\begin{array}{c}-0.0371^{* * *} \\
(0.00974)\end{array}$ & $\begin{array}{c}-0.0333^{* * *} \\
(0.00963)\end{array}$ & $\begin{array}{c}-0.0535^{* * *} \\
(0.0108)\end{array}$ \\
\hline ln_APS & $\begin{array}{l}0.0501^{* * *} \\
(0.00721)\end{array}$ & $\begin{array}{l}0.0463^{* * *} \\
(0.00691)\end{array}$ & $\begin{array}{l}0.0581^{* * *} \\
(0.00747)\end{array}$ & $\begin{array}{l}0.0568^{* * *} \\
(0.00713)\end{array}$ & $\begin{array}{l}0.0575^{* * *} \\
(0.00728)\end{array}$ & $\begin{array}{l}0.0573^{* * *} \\
(0.00728)\end{array}$ & $\begin{array}{l}0.0342^{* * *} \\
(0.00624)\end{array}$ \\
\hline ln_PMA & $\begin{array}{c}0.000653^{* * *} \\
(0.000147)\end{array}$ & $\begin{array}{c}0.000578^{* * *} \\
(0.000145)\end{array}$ & $\begin{array}{c}0.000717^{* * *} \\
(0.000147)\end{array}$ & $\begin{array}{c}0.000679 * * * \\
(0.000145)\end{array}$ & $\begin{array}{c}0.000705^{* * *} \\
(0.000147)\end{array}$ & $\begin{array}{c}0.000708^{* * *} \\
(0.000148)\end{array}$ & $\begin{array}{c}0.000445^{\text {*** }} \\
(0.000143)\end{array}$ \\
\hline ln_PMDN & $\begin{array}{c}0.000605^{\text {*** }} \\
(0.000131)\end{array}$ & $\begin{array}{c}0.000623^{* * *} \\
(0.000131)\end{array}$ & $\begin{array}{c}0.000730^{* * *} \\
(0.000134)\end{array}$ & $\begin{array}{c}0.000755^{* * *} \\
(0.000133)\end{array}$ & $\begin{array}{c}0.000766^{* * *} \\
(0.000135)\end{array}$ & $\begin{array}{c}0.000719^{* * *} \\
(0.000134)\end{array}$ & $\begin{array}{c}0.000512^{* * *} \\
(0.000127)\end{array}$ \\
\hline Constant & $\begin{array}{c}1.188^{* * *} \\
(0.164)\end{array}$ & $\begin{array}{c}0.693^{* * *} \\
(0.125)\end{array}$ & $\begin{array}{c}0.832^{* * *} \\
(0.136)\end{array}$ & $\begin{array}{c}1.063^{* * *} \\
(0.142)\end{array}$ & $\begin{array}{c}0.935^{* * *} \\
(0.135)\end{array}$ & $\begin{array}{c}0.814^{* * *} \\
(0.131)\end{array}$ & $\begin{array}{c}1.371^{* * *} \\
(0.171)\end{array}$ \\
\hline Observations & 6,875 & 6,875 & 6,875 & 6,875 & 6,875 & 6,875 & 6,875 \\
\hline adj. R-sq & 0.081 & 0.082 & 0.071 & 0.083 & 0.077 & 0.071 & 0.108 \\
\hline $\begin{array}{l}\text { Number of id } \\
\lambda\end{array}$ & $\begin{array}{c}505 \\
\mathbf{1 4 , 4 \%}\end{array}$ & $\begin{array}{c}505 \\
\mathbf{1 4 , 7 \%}\end{array}$ & $\begin{array}{c}505 \\
12,9 \%\end{array}$ & $\begin{array}{c}505 \\
\mathbf{1 4 , 2 \%}\end{array}$ & $\begin{array}{c}505 \\
13,2 \%\end{array}$ & $\begin{array}{c}505 \\
\mathbf{1 3 , 0} \%\end{array}$ & $\begin{array}{c}505 \\
\mathbf{1 8 , 0 \%}\end{array}$ \\
\hline $\mathbf{T}$ & 4,8 tahun & 4,7 tahun & 5,4 tahun & 4,9 tahun & 5,2 tahun & 5,3 tahun & 3,8 tahun \\
\hline
\end{tabular}

